\title{
ESTATE TAXATION OF EMPLOYEE DEATH BENEFITS
}

EnIPLOyeE death benefits constitute a comparatively recent compensation technique which combines production incentive with social security. ${ }^{1}$ Geared to the needs of individual businesses, these plans take a variety of forms differing significantly in manner of payment and method of financing. ${ }^{2}$ Such plans range in scale from the giant union-bargained package benefiting thousands of employees in a single industry to smaller arrangements designed primarily to reward corporate executives and other key employees. ${ }^{3}$ For complete success, plans of the latter type must be carefully attuned to the subtleties of estate taxation, since executives and other high income employees will normally face the incidence of a death tax. ${ }^{4}$

1. Employee death benefits are generally an integral part of retirement income or pension plans. For the history, development and purposes of such plans, see, generally, DEARing, Industrial Pensions 1-19 (1954) (hereinafter cited as Dearing); O'Neml, Modern Pension Plans 1-47 (1947) (hereinafter cited as O'Neill) ; Wyatr, Bjorn, Willianson, Bronson, Employee Retirenent Plans 1-12 (1945) (hereinafter cited as Wyatr).

2. Death benefits are a peculiarly personal type of compensation, and plans are often flexibly arranged to suit the needs of individual employees. For example, one employee may wish his beneficiary to receive a lump sum payment, while another would prefer a survivorship annuity with installment payments. Individualizing features are numerous; for discussion of the many options available, see Beck, Family Benefits and Family Security: Employee Death Payments, N.Y.U. 13Th Inst. oN Fed. TAX. 471 (1955); Yohlin, Employer Payments to the Widow of a Deceased Employee, 34 Taxes 87 (1956). As the text reveals passim, the exact features chosen, however, may have widely differing estate tax consequences.

Moreover, the employer may choose from several methods of administering his plan. He may purchase formal contracts from insurance companies, establish a trust fund without the facilities of a professional insurer or contract informally with his employee's without setting aside special funds. And other alternatives are available. On the general problems of creating and implementing death benefit plans, see Colgan, How to Provide Death Beilefits Before and After Retirement, N.Y.U. 12TH INST. on FED. TAX. 391 (1954); Nelson, The New \$5,000 Death Benefit, 31 Taxes 629 (1953). See also Beck, supra; Yohlin, supra. The precise method which the employer chooses may significantly affect his employees' estate tax liabilities.

3. For examples of union-negotiated death benefits, see 2 BNA, Collective Bargainwo Nerotutuons and Contracts 44:337 (1956), 53:619 (1955).

For discussion of death benefits paid executives and other key employees, see Allison, Deferred Compensation of Executives, 1954 Tul. Tax Inst. 105; Bilder, Death Benefits Paid Inder an Express Contract, 34 Taxes 529 (1956) ; Childs, Deferred Compensation Plans for Executives, 31 Taxes 1007 (1953) ; Diamond, Tax Aspects of Nonqualified Pension and Deferred Payment Plans, 32 Taxes 615 (1954); Lefevre, Deferred Compensation Plans, N.Y.U. 15Th INST. on FED. TAX. 1081 (1957); Long, Deferred Compensation for E.recutives, 24 TENN. L. Rev. 285 (1956) ; Rice, Incentives for Executives of Small Corporations, 32 TAXES 222 (1954).

4. These employees may expect to have gross estates the value of which will exceed the minimal estate tax exemptions. See Int. Rev. Code of 1954, \$§ 2052, 2056; note 20 infra. A major purpose of death benefit plans in this context is avoidance of high income tax rates by deferred compensation. However, unless estate tax consequences are antici- 
Before the 1954 Code, estate taxation of employee death benefits derived from a maze of individual provisions each differing in history and impact. Often conflicting in the type of liability imposed, and sometimes overlapping in scope, these provisions reached property interests of a general testamentary character with varying effect. Designed to mark the broad outlines of the estate tax, the structure was ill-suited to the unique problems raised by employee death benefits. As a result, taxation in this area became confused..$^{6}$ Often, the precise tax consequence of any given death benefit turned upon purely formal distinctions which made decisions unpredictable and estate planning hazardous, if not impossible.

Against this background, the 1954 Code revision is disappointing. Although the employee death benefit is recognized as a distinct taxable entity for the first time, ${ }^{7}$ the Code fails to provide a uniform scheme for taxing its many forms. ${ }^{8}$ Instead, new categories have been superimposed upon old, and the entire structure retains dated terminology, ensnarled in troublesome precedent and confused interpretation. And while tax consequences attending differences of terminology are even more crucial than before, distinctions among various applicable labels are, if anything, less precise. Thus, estate taxation of employee death benefits remains problematical. This Comment will survey the several estate tax provisions currently applicable to employee death benefits and suggest methods of analysis for resolving their conflicting principles of taxation into an administratively workable structure. ${ }^{9}$

pated, this liability may partially cancel income tax gains. See INT. Rev. CoDE of 1954, $\S 2001$ (estate tax rates).

5. Under the 1939 Code, no estate tax section dealt specifically with employee death benefits. Instead, provisions taxing "property" in general were most frequently applied to death benefits other than insurance. See Int. Rev. Code of 1939, § 811(a), 53 STAr. 120 (property in which decedent held an interest at death); $\$ 811(\mathrm{c})$, as amended, 67 STAT. 623 (1953) (inter vivos property transfers of testamentary character); $\$ \$ 11$ (d), as amended, 67 Stat. 623 (1953) (revocable transfers); $\$ \$ 11(\mathrm{f}$ ), as amended, 65 STAT. 91 (1951) (property subject to powers of appointment). Application of these provisions to employee death benefits became mired in technical property law distinctions. See notes 60-69 infra and accompanying text.

Estate taxation of insurance benefits was a major exception to this scheme. Int. Rev. Code of 1939, $\$ 811(\mathrm{~g})$, as amended, 56 STAT. 944 (1942), dealt specifically with life insurance. Section $811 .(\mathrm{g})$ included insurance proceeds in a decedent's gross estate on the basis of his payment of premiums during life or possession of incidents of ownership at death. This approach is altered by the 1954 Code. See note 34 infra.

6. "The greatest confusion over the tax consequences of a death benefit payment lies in the estate tax field." Nelson, supra note 2, at 632. For a sampling of the difficulties under the 1939 Code, see 3 Rabkin \& Johnson, Federal Incoare, GrFt and Estate Taxation $\$ 63.05(5)$ (1944) (hereinafter cited as RabKin \& JoHNSON); Young, $D e-$ ferred Pay Plans-Qualified and Non-Qualified Plans, N.Y.U. 13tr Inst. on FED. TaX. 457 (1955); text at notes 61-67 infra.

7. INT. REv, CODE of 1954, § 2039; see note 22 infra.

8. For "annuities," taxation depends on $\$ 2039$. For life insurance, $\$ 2042$ is applicable. When neither section applies, death benefits may be taxed under the varying provisions of $\S \S 2033-38,2040-41,2043$.

9. Only death benefits payable in accordance with a contract or other pre-death arrangement are considered; post-death gifts or other manifestations of employer generosity are 


\section{Current Labels and Their Consequences}

\section{Qualified plans-An Exemption}

The 1954 Code encourages employers to establish retirement and death benefits for their employees by conferring broad tax advantages upon plans qualifying under section $401 .^{10}$ This policy is carried into the estate tax by section 2039(c) which excludes from the employee's gross estate the benefits attributable to employer contributions to "qualified" plans. ${ }^{11}$ "Qualified" plans, however, are subject to strict conditions which limit their availability. The exemption of section 2039 (c) is not obtainable unless the plan confers death benefits upon either a substantial percentage of all employees or upon a class of employees which does not discriminate in favor of executives or other supervisory personnel. ${ }^{12}$ Even when the exemption applies, it does not reach the

omitted. Also, this Comment deals with income or gift tax implications of death benefit plans only where critical to problems of estate taxation.

10. See note 12 infra; 1 Rabkin \& JoHnson $\$ \$ 15.01-.05$.

Several provisions of the 1954 Code implement this scheme. For example, the emplayer's contributions to a qualified plan, within prescribed limitations, are currently deductible from income tax; excess contributions may be deducted in succeeding years. INT. REv. CODE OF 1954, § 404(a) (7). If the qualified plan is administered by means of a trust, as is generally the case, the trust's income is also exempt from taxation in most instances. Id. $\$ \$ 501(\mathrm{a}), 511-14$.

Favorable tax treatment of qualified plans enures to employees and their beneficiaries as well as employers. The major benefit given the employee is a deferment of taxable income; he pays no tax until amounts are distributed or actually made available to him. Id. $\$ 402$ (a) (1). Distribution under a qualified plan may result in only capital gains taxation to the distributee. Id. $\$ \$ 402(a)(2), 403(a)(2)$. And such distribution may fall within the $\$ 5,000$ exemption for employee death benefits. $I d$. $\S 101(\mathrm{~b})$. See, generally, Alexander, Adrantages and Disadrantages of Pension, Profit-Sharing and Stock Bomis Plans: A Discussion, N.Y.U. 14tr INST. ON FED. TAx. 1251, 1252-54 (1956).

11. INT. REv. CODE of 1954, $\$ 2039$ (c). The relevant portions of this provision state: “... [T] here shall be excluded from the gross estate the value of an annuity or other payment receivable by any beneficiary (other than the executor) under-

(1) an employees' trust ... forming part of a pension, stock bonus, or profitsharing plan which ... [meets] the requirements of section 401 (a); or

(2) a retirement annuity contract purchased by an employer ... pursuant to a plan which ... [meets] ... the requirement of section 401 (a) (3).

If such amounts .... are attributable to any extent to payments or contributions made by the decedent, no exclusion shall be allowed for that part of the value of such amounts in the proportion that the total payments or contributions made by the decedent bears to the total payments or contributions made. For purposes of this subsection, contributions or payments made by the decedent's employer or former employer under a trust or plan described in this subsection shall not be considered to be contributed by the decedent."

See H.R. Rep. No. 775, 85th Cong., 1st Sess. 37 (1957) (reporting H.R. 8381 which would amend $\$ 2039$ (c) to exempt only those annuities meeting all the requirements of $\S 401$ (a) instead of only $\S 401$ (a) (3)).

12. Before $\$ 2039$ (c) applies, the death benefit plan must "qualify." See INT. Rev. CoDE of $1954, \S 2039$ (c). For a qualified status, two alternatives are available. Under INr. REv. CODE OF 1954, $\$ 401$ (a) (3) (A), the plan must cover seventy per cent of all employees, or at least eighty per cent of those eligible to benefit under the plan if at least seventy per 
benefits which reflect the employee's own out of pocket contributions to the plan, for section 2039 (c) includes in his gross estate that value which is in the same proportion to the total benefits as the employee's contributions bear to the total contributions. ${ }^{13}$

As a practical matter, qualified plans confer relatively slight estate tax advantages. Whether or not a plan qualifies under section 401 , if the benefits provided are considered "life insurance," the exemption of section 2039(c) does not apply. ${ }^{14}$ The taxability of these benefits, as insurance, is determined

cent are eligible. However, in computing these percentages, employees who have not been employed for a prescribed minimum period or whose customary employment is not more than twenty hours weekly or five months yearly are excluded. Alternatively, the plan may establish a classification for qualified benefits, if, but only if, such classification does not discriminate in favor of officers, shareholders, supervisors or other highly compensated employees. Id. $\$ 401$.(a) (3) (B). Thus, selected groups of lower-salaried employees may be compensated by qualified plans. But under neither alternative can the contributions or benefits provided discriminate in favor of key employees. Id. $\$ 401$ (a) (4). See 1 RABKIN \& JoHNSON $\S 15.05$.

The plan must be for the exclusive benefit of the employees or their beneficiaries, and contributions to a qualified trust must be made for the purpose of distributing corpus and income to employees or their beneficiaries. INT. Rev. CoDE of 1954, $\$ 401$ (a) (1). Prior to the satisfaction of all obligations under the plan, it must be impossible to divert the funds to other uses. $I d$. $\S 401$ (a) (2).

13. INT. Rev. CoDE of 1954, § 2039(c); note 11 supra.

14. Apparently, the Code's drafters intended to make $\$ \$ 2039$ and 2042 mutually exclusive. For $\$ 2039$ (a) is specifically not applicable to amounts receivable as "insurance under policies on the life of the decedent." But the exemption for qualified employee death benefits provided in $\$ 2039$ (c) is stated in broad language which does not in terms distinguish between "annuities" and "insurance." And no discernible policy reason appears for such a distinction, once a plan is qualified. See note 16 infra. Notwithstanding the apparent breadth of $\S 2039$ (c), the regulations limit this exemption to only those payments ordinarily within $\$ \$ 2039$ (a), (b). Proposed U.S. Treas. Reg. \$ 20.2039-2(a), 21 FED. REG. 7878 (1956). Consequently, "insurance" proceeds paid under a qualified plan are not exempt under $\$ 2039$ (c), since such proceeds are ordinarily taxed by $\S 2042$ and not $\S \S 2039$ (a) or (b). Ibid. For the opposite view, that qualified insurance proceeds were intended to be exempt under $\$ 2039$ (c), see Cardon, Final Regulations Clarify Rules on Distributions Under Pension and Profit-Sharing Plans, $6 \mathrm{~J}$. Taxatron 100, 102 (1957).

On the other hand, the Commissioner's interpretation is consistent with current income tax treatment of insurance. The income tax provisions disfavor insurance as an integral part of a qualified plan. Specifically, contributions by the employer to certain types of non-forfeitable insurance coverage, even when incident to a qualified plan, must be reported as income by the participating employee. U.S. Treas. Reg. $\$ 1.402$ (a)-1(a) (3) (1957); Lawthers, The Individual Life Insurance Policy Issued in Conmection with a Qualified Employee Trist, 35 TAXEs 173, 174 (1957). Given this income tax approach, it might be argued that employer contributions to the cost of insurance are not "contributions to a plan" within the meaning of $\$ \S 401-04$. Such contributions would consequently be attributed to the decedent employee for purposes of $\$ 2039$ (c). But $\$ 2039$ (c) exempts only the employer's contributions to a qualified plan, and not the employee's. Therefore, on this view, insurance is properly excluded from $\$ 2039$ (c).

For the meaning of "insurance," see text at notes 73-\$2 infra. For the tax consequences of this label, see text at notes 33-39 infra. 
by section 2042 which, according to the regulations, does not recognize an exemption for qualified plans. ${ }^{15}$ Employees who receive life insurance protection under qualified plans will thus lose the exemption of section 2039(c), though the policy reasons for this result are not clear. ${ }^{16}$ And when a substantial amount of insurance coverage is provided, the plan may not even qualify under section 401.17 Moreover, since qualified plans can not discriminate in favor of influential employees, ${ }^{18}$ they are too costly for use primarily in compensating key executives. ${ }^{19}$ For benefits conferred upon the highest salaried employees must be proportionate to those of the lowest. Yet, only the highest salaried need ordinarily concern themselves with the estate tax; most employees will

15. The regulations specifically confine the exemption for qualified plans to death benefits otherwise taxable under $\$ \$ 2039$ (a), (b). Since these subsections exclude insurance, the exemption cannot, under Treasury interpretation, include insurance payments. See Proposed U.S. Treas. Reg. \$ 20.2039-2(a), 21 FED. REg. 7878 (1956); note 14 supra. Section 2042 does not distinguish between qualified and non-qualified plans. To be includible under $\$ 2042$ the benefits must only be receivable "as insurance under policies on the life of the decedent." See text at notes 33-39 infra.

16. The income tax also discriminates against insurance coverage provided by a qualified plan. Employer contributions to certain types of insurance coverage are treated as current income to the employee, U.S. Treas. Reg. \$ 1.402 (a) - (1) (a) (3) (1957) ; Gordon, Pension and Profit Sharing Plans for Medinm and Small Business, 1955 TUL. TAx INST. 231, 242; Bomar, How Benefits Arc Taxed to Employees, in HAxdBoor For PENSION PLANNING 217 (1949), while income taxation of contributions to a qualified plan for purposes other than insurance protection is ordinarily deferred until death benefits are actually received. INT. REv. CODE of 1954, $\$ 402$ (a) (1), 403(a) (1). See, generally, Lawthers, supra note 14.

In the estate tax, discrimination against insurance proceeds incident to a qualified plan may be construed as merely an extension of the income tax scheme. But this justification appears unsound, for the estate tax does not distinguish between "current" and "deferred" tax events. Rather, the estate tax is imposed broadly unon property owned by the decedent at death. Since legislative policy favors exempting qualified annuities from a decedent's taxable property at death, the same policy would seem to apply when qualified insurance proceeds are involved. See pages $1249-50$ infra.

17. A plan will not qualify if the employer's contributions are solely for the purpose of providing employees with insurance protection; a qualified status is obtainable, however, if insurance benefits are merely "incidental." U.S. Treas. Reg. $\S 1.401-1$ (b) (1) (1957) ; see also Rev. Rul. 54-67, 1954-1. Cuks. Bunz. 149; Gordon, supra note 16, at 24144. For an example of insurance benefits permissible under a qualified plan, see U.S. Treas. Reg. $\$ 1.402(a)-(1)(a)(3)$ (1957).

Even if insurance benefits are "incidental," most qualified plans likely to be approved will give the employee one or more "ineidents of ownership" in the policy. The proceeds will then be subject to estate tax liability under $\$ 2042$. See Bomar, supra note 16, at 22830 . But the employee may avoid this liability by divesting himself of control over the policy. See text at note 38 infra. See also Rev. Rul. 54-398, 1954-2 Cum. Burl. 239; cf. Rev. Rul. 56-656, 1956 INT. Rev. BuLL., No. 51, at 13.

18. See note 12 supra.

19. Young, supra note 6 , at 458 . However, the qualified plan can be employed to supplement more conventional methods of compensating valued personnel. See Lefevre, supra note 3 , at 1082 . In a limited number of situations involving closely held corporations or other small enterprises, the qualified plan may be used specifically to compensate executives. Cf. Gordon, supra note 16 , at 235. 
not possess property of sufficient aggregate value to incur this liability in the first instance. ${ }^{20}$ Consequently non-qualified plans will remain the major vehicle for compensating favored employees by means of death benefits, and in this area the estate tax plays a major role.

\section{Annuities vs. Life Insurance}

In the area of non-qualified plans, estate tax treatment of most employee death benefits hinges upon their identification as either "annuities" or "life insurance" within sections 2039 and 2042 respectively. ${ }^{21}$ Section 2039 is a comprehensive attempt to subject the death benefit portions of survivorship annuities, or other similar contracts, to estate tax liability if during life the decedent possessed any rights to payment, such as retirement income, under his contract. ${ }^{22}$ This provision includes in the gross estate the value at death of

20. Death benefits have no estate tax consequences unless the decedent's gross estate totals at least $\$ 60,000$, the basic exemption granted by $\$ 2052$. This exemption, combined with the marital deduction of $\S 2056$, permits most decedents to leave property valued at $\$ 120,000$ free of the estate tax.

21. A limited number of plans will not fall within either section. See notes 127-28 infra and accompanying text.

22. InT. Rev. CoDE of 1954, \& 2039. The relevant portions of this provision state: "(a) The gross estate shall include the value of an annuity or other payment receivable by any beneficiary by reason of surviving the decedent under any form of contract or agreement ... (other than as insurance under policies on the life of the decedent), if, under such contract or agreement, an annuity or other payment was payable to the decedent, or the decedent possessed the right to receive such annuity or payment, either alone or in conjunction with another for his life or for any period not ascertainable without reference to his death or for any period which does not in fact end before his death.

(b) Subsection (a) shall apply to only such part of the value of the annuity or other payment receivable under such contract or agreement as is proportionate to that part of the purchase price therefor contributed by the decedent. For purposes of this section, any contribution by the decedent's employer ... to the purchase price of such contract or agreement ... shall be considered to be contributed by the decedent if made by reason of his employment."

Before the 1954 Code', no estate tax provision dealt directly with survivorship annuities and similar benefits. Some courts analogized the survivorship annuity to a transfer with a retained life estate, see, e.g., Commissioner v. Clise, 122 F.2d 998 (9th Cir. 1941), crrt. denied, 315 U.S. 821 (1942), while others considered the survivorship rights a transfer intended to take effect at the decedent annuitant's death, see; e.g., Commissioner v. Wilder's Estate, 118 F.2d 281 (5th Cir.), cert. denied; 314 U.S: 634 (1941). Taxation of employee death benefits in this form was hampered due to technical considerations incident to these constructions. Lowndes \& Kraraek, Federal 'Estate and Gift Taxes 50-52, 152-59 (1956) (hereinafter cited as LowNDE' \& KRAirer) ; Bittker, Estate and Gift Taxation Under the 1954 Code: The Principal Changes, 29 TuL. L. Rev. 453, $468-70$ (1955). See also notes 60-69 infra and accompanying text. Section 2039 attempts to eliminate technical requirements which previousiy thwarted estate taxation of survivorship annuities. S. Rep. No. 1622, 83d Cong., 2d Sess. 123 (1954) ; H.R. Rep. No. 1337, 83d Cong., 2d Sess. 90-91, A314 (1954). The single definition 'of taxable annuities set forth is intended to be exhaustive. But the statutory language may not successfully implement this intent. See text at notes $25-28$ infra. 
all benefits in the proportion which the decedent's own contributions bear to the total cost of the plan. For purposes of employee death benefits, contributions to the purchase price by an employer for any reason connected with the employment are regarded as if made by the decedent employee himself. When employer and employee together bear the entire cost of an annuity, the full value of all proceeds is thus included in the latter's gross estate. ${ }^{23}$ And the liability of section 2039 is impased whether or not the employee had power during life to control disposition of the proceeds at death. ${ }^{24}$

Despite the apparent breadth of section 2039, the statutory language is ambiguous and may fall short of its objectives. For example, this provision speaks of a decedent's "right to receive payment" and of benefits "payable" during life. ${ }^{25}$ If strictly construed, this language may exclude benefits which prior to a decedent's death were forfeitable, terminable or otherwise defeasible. ${ }^{26}$ Such benefits may not be "payable" within the meaning of section 2039, and the decedent's interest may be an "expectancy" rather than a "right to receive payment." 27 Similarly, when an employer does not purchase a plan from an insur-

23. See Proposed U.S. Treas. Reg. $\$ 20.2039-1$ (c) (example 2), 21 FED. REG. 7876 (1956).

24. Compare the estate tax treatment of insurance under $\$ 2042$, in which control and not contributions to cost is the touchstone. See text at notes 33-39 infra.

25. InT. Rev. CODE of 1954, § 2039.

26. The employee's interest in retirement-death benefit plans is generally forfeitable or otherwise terminable. The more common contingencies include: 1) continuity of services until payment or retirement date whichever is earlier; 2) continuity of services after retirement in consultative or advisory capacity ; 3 ) non-competition with employer. Lefevre, supra note 3, at 1086-87. See, generally, Allison, stpra note 3, at 119-21. These contingencies are thought sufficient to enable the employee to postpone recognizing employer contributions as income until actual receipt of benefits. See U.S. Treas. Reg. $\$ 1.402$ (b) -1 (a) (1) (1957) ; Bock, Tax-saving Opportunities in Deferred Compensation under the New Revenue Code, $99 \mathrm{~J}$. Accountancy 39, 41 (March 1955) ; Diamond, supra note 3, at 618; Lefevre, supra note 3, at 1088; Rice, supra note 3, at 226-29. Forfeiture clauses also encourage valued employees to continue their employment. Lefevre, supra note 3 , at 108S. Such conditions, however, may cause the employer to lose his deductions for contributions to non-qualified plans. William M. Bailey Co., 15 T.C. 468 (1950), aff'd per curiam, 192 F.2d 574 (3d Cir. 1951) ; Times Publishing Co., 13 T.C. 329 (1949); U.S. Treas. Reg. $\$ 1.404$ (a)-12 (1957); Nelson, supra note 2, at 637; Rice, supra note 3, at 226; Note, 70 HARv. L. REv. 490, 508-09 (1957). Nevertheless, as a statistical fact, the majority of death benefits are forfeitable at the time when the employer contributes his funds. Couper \& Vaughan, Pension Planning Experience and Trends 121. (1954) (hereinafter cited as COUPER \& VAUGHAN).

27. Death benefits are not subject to $\S 2039$ unless an annuity or other payment was "payable to the decedent" or the "decedent possessed the right to receive such annuity or payment" during his lifetime; in addition the benefits must have been "receivable" by the decedent's beneficiary. This language lends itself to technical distinctions derived from pre-1954 case law. Prior to the 1954 Code, if the employee's rights to death benefits were contingent or forfeitable, he was regularly held to possess merely an "expectancy" and not "property." See, e.g., Estate of William S. Miller, 14 T.C. 657, 664 (1950) ; note 64 infra (collecting cases) and accompanying text. At that time, estate taxation of employee death benefits depended exclusively upon provisions taxing the decedent's "property." See 
ance company and instead pays death benefits directly, he may not have made the "contributions" necessary under section 2039.28 Many courts were receptive to analogous arguments under provisions governing before the 1954 Code. $^{20}$ But the current regulations emphatically reject such semantic technicalities, ${ }^{30}$

Int. Rev. Code of 1939, $\$ 811$ (a), (c), (d), (f), as amended, 67 Stat. 623 (1953) ( now INT. REv. CoDE of 1954, $\$ \S 2035-38,2041)$; notes $60-69$ infra and accompanying text. Loopholes created under the "expectancy" approach led to $\$ 2039$, which was intended to avoid property law distinctions. See note 22 supra; see also Murphy, The Survivorship Amuity: Estate Tax Kaleidoscope, 1 Howard L.J. 1, 3-29 (1955). But $\$ 2039$ may fail to solve problems created by the pre-1954 cases. For example, if during life, the decedent received no actual payments and his interest in death benefits was forfeitable, it may be argued that the decedent lacked the requisite "right to receive" payment, or that benefits were not "receivable" by his beneficiary within the meaning of $\$ 2039$. If pre-1954 case law is controlling, he may possess merely an expectancy and no "right" at all. Similarly, even if the decedent was receiving actual payments, the benefits are conceivably not "payable to the decedent" within $\$ 2039$ if he possessed merely an "expectancy." See, generally, Lowsdos \& Kramer 157, 158; Warren \& Surrey, Federal Estate and Gift Taxation 284-85 (1956) (hereinafter cited as WARREN \& SURREY). For the current applicability of the pre1954 case law to non $\$ 2039$ benefits, see text at notes 57-71 infra; Garner, Incone and Estate Taxation of Amnities, N.Y.U. 13TH INST. ON FED. TAX. 265, 284-90 (1955); Murphy, supra at 29-39.

28. Section 2039(b) includes in the decedent's gross estate amounts attributable to his contributions to the plan. And "any contribution by the decedent's employer . . . to the purchase price" is treated as a contribution of the decedent in determining his gross estate. INT. REv. CODE of 1954, § 2039 (a). Thus if the employer pays the total employee benefits directly without utilizing contracts purchased from a standard insurance company, it may be argued that a contribution attributable to the decedent does not exist. Bittker, Estate and Gift Taxation Under the 1954 Code: The Principal Changes, 29 Tuz. L. Rev. 453, $471 \&$ n.62 (1955). Support for this argument derives by negative inference from the income tax. Compare INr. REv. CODE of 1954, $\$ 105$ (a)'s specific taxation of direct employer payments to employees under accident and health plans with $\$ 2039^{\circ} \mathrm{s}$ omission to include direct employer payment of death benefits. The argument has been rejected, however, by some commentators, see, e.g., Garner, supra note 27 , at 286-\$7, and, apparently, by the regulations, see note 30 infra.

29. See notes 27 supra, 64 infra.

30. The regulations consider employer contributions to a self-administered plan attributable to the decedent for purposes of $\$ 2039$ (b). Proposed U.S. Treas. Reg. $\$ 20.2039-1$ (b) (examples 2-6), (c) (example 2), 21 Fen. REg. $7876-77$ (1956). The Treasury does not specifically comment, however, on cases involving plans that are non-funded and payments from general funds, though in principle they seem the same as the examples. See Garner, supra note 27, at 286-88.

The treatment of other semantic arguments is equally vigorous. For example, the regulations interpret $\$ 2039$ as follows:

"An annuity or other payment 'was payable' to the decedent if, at the time of his death, the decedent was in fact receiving an annuity or other payment, whether or not he had an enforceable right to have payments continued. The decedent 'possessed the right to receive' an annuity or other payment if, immediately before his death, the decedent had an enforceable right to receive payments at some time in the future, whether or not, at the time of his death, he had a present right to receive payments." Proposed U.S. Treas. Reg. $\$ 20.2039-1$ (b) (2), 21 FED. REg. 7877 (1956). This regulation clearly forecloses an argument of "unenforceability" where the decedent was in fact receiving payment before death, and demonstrates that once a right to future payment be- 
and section 2039 itself was intended to close loopholes suggested by earlier cases. ${ }^{31}$ The courts should therefore liberally interpret this provision, and as a general rule, amounts attributable to contributions by employers and employees to death benefit plans characterized as "annuities" should be subject to estate taxation under section 2039. ${ }^{32}$

On the other hand, death benefits regarded as "insurance" incur the less rigorous treatment of section 2042.33 The touchstone for estate taxation then becomes the decedent's control over the policy at death and not contributions to cost as in section 2039. ${ }^{34}$ While the proceeds of insurance receivable by the

comes enforceable, conditions deferring the time of payment will not avoid $\S 2039$. While in spirit cutting across semantic obstacles to taxation, it leaves unanswered the question of what constitute's an "enforceable right." The illustrations suggest that "forfeitability" of benefits does not render $\$ 2039$ inapplicable. $I d$. examples 2,3 . But the regulation expressly meets the "expectancy" argument on forfeitable rights only where the decedent was actually receiving payment during life. $I d$. $\$ 20.2039-1$ (b) (2). Whether or not the pre-1954 "expectancy theory" carries over to $\$ 2039$ is currently disputed by the authorities. Compare Garner, supra note 27, at 285; Pyle, Income, Estate and Gift Taxation of Life, Accident and Sickness Insurance and Anmities under the 1954 Code, 1956 TULANE TAX INST. 467, 658-59, with Murphy, supra note 27, at 36; Note, 6 STAN. L. REv. 473, 489 (1954). Cf. G.C.M. 27242, 1952-1 CuM. Bull. 160. If it does, this section will be severely weakened, since the majority of death benefit plans are forfeitable. See note 26 supra. But see notes 31, 32 infra and accompanying text.

31. See nate 27 supra. The congressional reports tend to support the view that $\$ 2039$ was meant to provide a uniform scheme of taxation for all survivorship annuities irrespective of source or method of payment. See S. REP. No. 1622, 83d Cong., 2d Sess. 123 (1954) ; H.R. REP. No. 1337, 83d Cong., 2d Sess. 90-91, A315 (1954). Arguments from the wording of $\S 2039$ or from property law technicalities would seem inconsistent with this purpose and should be rejected. And apart from $\$ 2039$, the distinctions were never realistic. See notes 128-35 infra and accompanying text.

32. If technical arguments from the "expectancy" theory successfully avoid $\$ 2039$, taxation of the benefits depends on other provisions of the Code. See text at notes 59-69 infra. Since these provisions tax only "property," avoidance of $\$ 2039$ may be equivalent to avoidance of all estate taxation. Ibid.

33. INT. REv. CoDE of 1954, $\S 2042$. This provision is "less vigorous" because it is avoidable. See text at notes 38-40 infra. Section 2039 (a) specifically excludes insurance proceeds from its operation. For discussion of the meaning of "insurance," see text at notes 73-82 infra.

34. The relevant portions of INT. REv. CoDE of 1954, § 2042 provide:

"The value of the gross estate shall include the value of all property

(1) Receivable by the executor ...

(2) Receivable by other beneficiarie's.

To the extent of the amount receivable by all other beneficiaries as insurance under policies on the life of the decedent with respect to which the decedent possessed at his death any of the incidents of ownership, exercisable either alone or in conjunction with any other person. ..."

Prior to 1954, insurance proceeds were included in the gross estate if the decedent retained control over the policy or if he paid the premiums, directly or indirectly. Int. Rev. Code of 1939, $\$ 811(\mathrm{~g})$, as amended, 56 STAT. 944 (1942). Section 2042 dropped the premium payment test. See H.R. Rep. No. 1337, 83d Cong., 2d Sess. 91, A316-17 (1954), S. REP. No. 1622, 83d Cong., 2d Sess. 124 (1954). The proper test for taxation of insurance 
decedent's executor or estate are included in the gross estate, those receivable by all other beneficiaries are taxable only if the decedent possessed at death "incidents of ownership" in the policy. ${ }^{35}$ This term refers to the insured's rights to the economic benefits of the policy, and encompasses powers to cancel, surrender or assign the policy, and to designate beneficiaries, as well as certain reversionary interests. ${ }^{36}$ Retention of any incident of ownership at death will bring into the decedent's gross estate the face amounts payable under the policies. $^{37}$ But the tax liability of section 2042 is easily avoided. For the proceeds of life insurance pass tax free to beneficaries if the insured divests himself of control more than three years before death. ${ }^{38}$ And this result follows whether or not the decedent contributed to the cost of the insurance. ${ }^{30}$

An employee's beneficiaries may thus receive the proceeds from insurance coverage purchased by the employer free of estate tax consequences if the employee's control over the proceeds is eliminated. An arrangement whereby the ordinary incidents of ownership are divested is readily provided.0 Sometimes, however, an employee may be unable to divest all control. For example, upon severance from employment, legislation in some states requires an insurance company providing group coverage to convert the employee's policy into an individual contract without loss of accrued benefits. ${ }^{41}$ When a new policy is

proceeds has been the subject of much debate. See text at note 136 infra. H.R. 8381, 85th Cong., 1st Sess. (1957) would reintroduce the premium payment test if the policy was purchased or transferred within five years of the decedent's death but only to the extent that the proceeds are attributable to premiums paid within that period. See H.R. REP. No. 775, 85 th Cong., 1st Sess. 37-38 (1957).

35. INT. Rev. CoDE of $1954, \S \S 2042(1)-(2)$.

36. See Proposed U.S. Treas. Reg. $\$ 20.2042-1$ (c) (2)-(5), 21 FED. Reg. 7885-\$6 (1956).

37. Int. Rev. Code of 1954, § 2042(2). See Proposed U.S. Treas. Reg. $\$ 20.2042-1$ (a) (3), 21 FED. REg. 7885 (1956).

38. If the insured does not possess the requisite incidents of ownership himself or in conjunction with another, $\$ 2042$ does not apply. 2 Beveridge, Federal Estate TAxation \$ 1.1 .06 (1956) (hereinafter cited as BEVERIDGE) ; Lowndes \& KRAMIER, 279; 3 RABKIN \& JoHNSON $\$ 61.05$. Insurance is no longer taxable merely because the decedent paid the premiums. Ibid. See note 34 supra. For discussion of the ease with which a tax is avoided under $\$ 2042$, in contrast with the former premium payment test, see BITTKER, FEDERAL. InCONE, ESTATE AND GIFT TAXation 1166-71 (1955); Lowndes \& KRAMrer 278-79; Bittker, Estate and Gift Taxation under the 1954 Code: The Principal Changes, 29 TuL. L. REv. 453, 464-67 (1955).

Divestment of control within three years of death may be a gift in contemplation of death under \$2035. Garrett's Estate v. Commissioner, 180 F.2d 955 (2d Cir. 1950); BitTKER, Federal Income, Estate ANd Gift TAXation 1168-70 (1955) ; Lowndes \& Kramer 288-89; Warren \& Surrey 530-31. But cf. Note, 66 Yale L.J. 142, 150 n.47 (1956). Consequently if the insured divests himself of all control over the policy more than three years prior to death, the proceeds are almost certain to be free from estate tax liability. Lowndes \& KRAMTER 298.

39. See note 34 supra.

40. See note 38 supra. If the insurance benefits are payable under a qualified plan, extra precaution must be taken in divesting control. See note 17 supra.

41. 3 RIA, Fen. TAx Coordinator R-4014. An illustrative statute is N.Y. INs. LAw $\S 161$ (e). The Model Group LIfe Insurance LAw, proposed by the National Association 
issued in this fashion, control formerly divested may, at least temporarily, return to the insured. Conversely, when not restrained by state law, employers may provide that all coverage terminates upon severance of the employment. ${ }^{42}$ In effect, the employee then has a power of revocation which he can exercise by leaving his job. ${ }^{43}$ Nevertheless, such controls need not be "incidents of ownership" under section 2042.44 Severance under a forfeitable plan may entail the employee's loss of all economic benefits of the insurance and therefore preclude his power of revocation from constituting an incident of ownership as defined by the regulations. ${ }^{45}$ Even where state law assures the employee of accrued benefits after severance, advance planning may prevent the return of substantial control to the insured when and if a new policy is issued in the future. ${ }^{46}$ Moreover, the necessity of leaving employment to exercise the "power"

of Insurance Commissioners and adopted in many states, makes mandatory a provision that, upon severance from employment, the insured may elect to take an individual policy on any plan but group term insurance. Merr \& OsLer, Modern Lrfe Insurance 262-63 (revised ed. 1956) (hereinafter cited as MEER \& OsLER).

42. Cf. Munch, Estate Tax Problems in Transfers of Life Instirance, N.Y.U. 15тH Inst. oN FED. TAX. 219, 223 (1957). However, most group insurance policies contain the privilege of conversion to permanent individual insurance upon termination of employment. O'NeIrl 224, 230; 3 Rabrin \& Johnson $\$ 62.04(3)$. See also Wyatr 76-77.

43. The regulations include the power to "cancel the policy" among the incidents of ownership under $\$ 2042$. Proposed U.S. Treas. Reg. \$ 20.2042-1 (c) (2), 21 FED. REg. 7885 (1956). It is arguable that the power to terminate insurance coverage by leaving employment is equivalent to the power to cancel and is therefore an incident of ownership. See note 44 infra. But see note 45 infra.

44. Apparently there is no authority as to whether the power to terminate group insurance coverage by leaving employment, or the power to convert group coverage into an individual policy by terminating employment, constitute "incidents of ownership." Thus, the commentators state that either of these powers "might" be an incident of ownership and acknowledge that the question remains open. 3 RABKIN \& JohNSON $\$ 62.04(3) ; 3$ RIA, Fed. TAX Coondinator R-4014; Munch, supra note 42, at 223 . The Commissioner would probably have a stronger case for an incident of ownership construction if the employee can terminate coverage merely by discontinuing his contributions.

45. An incident of ownership is defined as the right "to the economic benefits of the policy." Proposed U.S. Treas. Reg. \$ 20.2042-1(c) (2), 21 FED. REG. 7885 (1956). When the employee quits, he may forfeit all accrued benefits. See note 42 supra. In that event, he would receive no beneficial interest, and his power before severance would clearly not be an incident of ownership. Most often, however, the employee will have the option to receive accrued contributions upon severance. Ibid. This option is somewhat analogous to the power of obtaining the cash surrender value of an insurance policy, which is an incident of ownership. But this power merely returns deferred compensation to the employee, and does not give him rights directly in the benefits of the insurance policy.

46. The original plan establishing insurance coverage could include provisions designed to prevent the return of any incidents of ownership to the insured when and if he converts to an individual policy upon terminating employment. For example, the plan could provide that the group policy beneficiary automatically be made the beneficiary of the individual policy. Provisions could also be made to have other incidents of ownership vest in accordance with the group plan. However, if state law requires that the insured be given the power to designate the beneficiaries upon conversion, such an arrangement may not be possible. See N.Y. Ins. Law $\$ 161(1)(d)$. 
neutralizes control and militates against an "incident of ownership" construction. Accordingly, the employer would appear generally able to create a plan giving life insurance coverage to his employees free of estate tax liability.

However, employers may not be able to arrange tax free treatment when insurance proceeds are provided directly from their own funds and not through a standard insurance company. ${ }^{47}$ The pre-1954 case law suggests that death benefits paid by the employer may not be characterized as "insurance" within section 2042.48 And both Congress and the Commissioner leave the issue

47. Employee death benefit-retirement plans are generally financed in one of three ways : through a commercial insurance company or directly by the employer on a funded or non-funded basis. The employer "funds" a plan by establishing a trust or reserve to which he systematically contributes. Alternatively, the employer's arrangement may be quite informal or "non-funded" as when he obligates himself to pay death benefits sometime in the future without any present earmarking of funds for this purpose. See, general1y, Couper \& Vaughan 27-34; O'Neill 31-42; Sibson, A Survey of Pension Planning 15-23 (1953) (hereinafter cited as Sibson) ; St. John, Financing a Pension Plan, in HaNdBOoK For Pension Planning 83 (1949); Gordon, supra note 16, at 240.

Whether or not a death benefit is "insurance" depends in the first instance upon the function of the plan during the decedent's lifetime and its particular status at death; for analysis of the nature of insurance, see notes 73-82 infra and accompanying text. The discussion following in text assumes that the benefits conferred are functionally "insurance"; the problem is then whether such plans will be considered insurance for tax purposes.

48. See Estate of John C. Morrow, 19 T.C. 1068 (1953). Few case's squarely meet the issue; but the absence of a professional insurance company has consistently caused courts difficulty in classifying death benefits as "insurance." The size of the plan, its permanency and the extent to which the employer's performance resembles the operations of an insurance company are significant criteria. See Central Hanover Bank and Trust Co., 40 B.T.A. 268 (1939) (dictum); Estate of Max Strauss, 13 T.C. 159, 166 (1949) (majority and dissenting opinions), rev'd sub nom. Commissioner v. Treganowan, 183 F.2d 288 (2d Cir.), cert. denied, 340 U.S. 853 (1950). For example, considerations thought relevant have been whether a physical examination was required, see Helvering v. Le Gierse, 312 U.S. 531,537 (1941); Central Hanover Bank and Trust Co., supra at 271 (dictum); Estate of Max Strauss, supra at 165; and whether the plan is subject to state insurance regulation, Kernochan v. United States, 89 Ct. Cl. 507, 29 F. Supp. 860 (1939), cert. denied, 309 U.S. 675 (1940). And the Treasury regulations sugge'st that an employer's failure to maintain technical computations normally associated with professional insurers may be crucial. See discussion of "terminal reserve" and its implications at notes 78-82 infra. Furthermore, the extent to which the employer formalizes his obligations in a contract, and the certainty of payment from the employee's perspective, are important factors. See Dimock v. Corwin, 19 F. Supp. 56 (E.D.N.Y. 1937), aff'd, 99 F.2d 799 (2d Cir. 1938), aff'd, 306 U.S. 363 (1939); Illinois Merchants Trust, 12 B.T.A. 818, 820 (1928); sce also Note, 48 Colum. L. Rev. 393, 400-01 (1948); 1 Paul, Federal Estate and Gift TAXation $\$ 10.10$ (1942). Often, the promise of an employer is considerably less binding or enforceable than that of an insurance company, which supplies a formidable ground for distinction. Analogous distinctions exist for income tax purposes. Compare Guaranty Trust Co., 15 B.T.A. 20 (1929), with J. Darsie Lloyd, 33 B.T.A. 903 (1936). Compare also United States v. Drescher, 179 F.2d 863 (2d Cir. 1950), with J. D. Amend, 13 T.C. 178 (1949).

According to at least one author, the cases make it "doubtful that a death benefit paid by an employer could be subject to tax as insurance." Nelson, supra note 2, at 634. But the above cases were decided prior to 1954 on specific issues generally not pertinent under 
clouded under the Code. ${ }^{49}$ This possibility can adversely affect plans in which retirement income or other lifetime payment is a feature. Death benefits under such plans may be taxed as the survivorship portion of an annuity if they are not considered insurance. 50 The basis of liability would then become contributions to cost under section 2039 rather than control, and the ability to effect divestment would be inconsequential. ${ }^{51}$ In contrast, employees receiving identical coverage under formal policies issued by an insurance company would face only the avoidable tax burden of section $2042 .{ }^{52}$ Moreover, if no lifetime feature is involved, employer payments may comprise a third category reached neither by sections 2039 nor $2042 .{ }^{53}$ Estate taxation of the proceeds would then be determined by still different principles.

the present Code. Furthermore, several cuses declare that the mere absence of a standard contract from an insurance company should make no difference. See Commissioner v. Treganowan, supra; Kernochan v. United States, supra; Estate of William J. O'Shea, 47 B.T.A. 646 (1942) ; see also Note, 59 YALE L.J. 780 (1950). However, the actual holdings of these case's leave the matter unresolved.

49. The distinction between insurance benefits received from an insurance company and those paid directly by the employer may be perpetuated by H.R. REP. No. 1337, 83d Cong., 2d Sess. A315 (1954) and S. REP. No. 1622, 83d Cong., 2d Sess. 472 (1954) which in example 4 consider an "annuity" paid directly by an employer without the aid of an insurance company subject to $\S 2039$, although in fact it may functionally be insurance. Se'e note 114 infra (detailed evaluation of example 4); see also text at notes 102-14 infra. Furthermore, Congress has distinguished employer from standard insurance benefits for purposes of the income tax. Section 22(b) of the 1939 Code was amended to exempt employer insurance payments sometime after "insurance" was already exempt. See Int. Rev. Code of 1939, $\S 22$ (b) (1) (B), added by 65 Stat. 483 (1951). The same language was carried over into § 101. Compare INT. REv. CODE of 1954, § 101 (a) (1.) with § 101 (b) (1). This distinction for income taxation, and the lack of similar treatment in the estate tax, indicates that Congress intended employer paid benefits not to be "insurance." See Nelson, supra note 2, at 634. But see text at notes 102-14 infra.

The regulations studiously avoid the issue, but their examples lend fuel to the fire. An example is given of a contract purchased from a standard insurer for purposes of distinguishing between an "annuity" and "insurance." This example emphasizes the importance of the policy's "terminal reserve" in determining whether the proceeds are "annuity" or "insurance." Proposed U.S. Treas. Reg. § 20.2039-1(d), (example), 21 FED. REg. $7877-78$ (1956). For the meaning and implications of "terminal reserve," see notes 78-81 infra. Since employers paying death benefits may not ordinarily be expected to use "terminal" reserve computations, the regulations may not consider such benefits "insurance" by negative inference. This inference is strengthened by reference to examples elsewhere in the regulations which demonstrate the applicability of $\S 2039$ to employee death benefit retirement plans: the plans in these examples are all employer-funded. Proposed U.S. Treas. Reg. $\$ 20.2039-1$ (b) (2) (examples 2-6), (c) (example 2), 21 Fed. REg. 7876-77 (1956).

50. INT. REv. CODE of 1954, § 2039.

51. See note 22 supra.

52. See notes 38-39 supra and accompanying text.

53. Section 2039 applies only if the decedent was paid or had rights to be paid during his lifetime. Section 2042 is inapplicable by hypothesis. Therefore, the proceeds are taxable, if at all, as "property" under more general provisions of the estate tax. For tax treatment in this situation, see notes 60-69 infra and accompanying text. 
On the other hand, this distinction between commercial and employer-paid insurance benefits may confer tax advantages upon employees who participate in qualified plans. Ordinarily, despite a qualified status, the proceeds of life insurance remain taxable under section 2042 and are not exempted by section 2039 (c).${ }^{54}$ But if the qualified benefits are paid directly by the employer, and the proceeds are consequently not classified as insurance, the employee may be able to retain the exemption under section 2039 (c). ${ }^{55}$ The preferential treatment thus accorded some self-administered plans will affect firms differently depending upon their size. Smaller firms with limited financial resources must generally operate through an insurance company. ${ }^{56}$ Their employees may thus lose estate tax exemptions in situations where those of larger, self-insuring firms would not.

\section{Beyond Sections 2039 and 2042: An Anomalous Category}

Estate taxation of employee death benefits is further complicated by some plans which fall within neither sections 2039 nor 2042. Death benefits lacking any inter vivos feature are clearly not subject to section 2039.67 If in addition the arrangement contains no element of insurance, section 2042 is equally inapplicable. Some deferred compensation plans fit this description, since the employer may act merely as a repository for deferred employee earnings-like a savings bank-while conferring no risk shifting advantages. ${ }^{58}$ Although other sections of the Code may be available to tax such death benefits, these provisions turn upon technical property law doctrines which greatly impede their effectiveness. ${ }^{59}$

54. See text at notes 14-15 supra.

55. The employee will also be able to retain controls over the proceeds without incurring estate tax liability. See text at note 24 supra. But if the plan involves no lifetine feature, entirely different provisions govern. See notes 60-69 infra and accompanying text.

56. Insurance is based upon actuarial principles, which in turn depend upon data derived from large numbers of people for successful application. See notes 74-78, 112 infra. When small numbers are involved, actuarial predictions may not be realized, and the enterprise must bear the resulting loss. For this reason small companies generally adopt an "insured" plan. Gordon, supra note 16, at 241 \& n.24; SrBson 18.

57. See note 22 supra. Because of its ambiguous language, some plans with a lifetime feature may also escape $\$ 2039$. See text at notes $26-28$ supra. See also Garner, supra note 27 , at 283-90; Murphy, supra note 27, at 29-39.

58. See Note, 48 Colum. L. Rev. 393, 394-95 (1948) ; Diamond, supra note 3, at 61718; Lefevre, supra note 3, at 1081-83; Rice, supra note 3, at 225-26. For an example of a deferred compensation plan held to involve no element of risk shifting, see Knight v. Finnegan, 74 F. Supp. 900 (E.D. Mo. 1947). See also Helvering v. Le Gierse, 312 U.S. 531 (1941). These plans would currently be subject to $\$ 2039$ only where a lifetime feature is involved. Otherwise they are subject to still other estate tax provisions. See text at notes 60-69 infra.

59. The congressional reports specifically state that $\S 2039$ is not exclusive and that the provisions of $\$ 2039$ shall not prevent the application of other sections of the estate tax. S. REp. No. 1622, 83d Cong., 2d Sess. 472 (1954) ; H.R. Rep. No. 1337, 83d Cong., 2d Sess. A316 (1954). See also Proposed U.S. Treas. Reg. § 20.2039-1(d), 21 Fed. REg. 7\$77-78 (1956). Annuity proceeds or other payments may be taxable under $\$ 2033$ as property in 
For example, sections 2033 and 2041 respectively reach death benefits in which the decedent possessed a property interest at death or over which he retained a general power of appointment during life. ${ }^{60}$ They are inoperative, however, unless the interest which the employee possessed in the benefits amounted to a "property right" at death. ${ }^{61}$ And property in this connection is usually defined as a legally enforceable right to payment at, or prior to, death. ${ }^{62}$ For this reason, death benefits which prior to the employee's death were forfeitable, terminable or subject to the employer's discretion may escape taxation under sections 2033 and $2041 .{ }^{63}$ On the accepted view, such benefits are considered mere "expectancies" and not payable under vested, enforceable property rights. ${ }^{64}$ Even when the employee's expectation is based upon past

which the decedent had an interest at death; under $\$ 2035$ if decedent transferred the contract in contemplation of death; under $\$ 2037$ if decedent transferred the contract subject to a retained reversionary interest; as a revocable transfer under $\$ 2038$ if decedent retained the power to designate beneficiaries; or under $\S 2041$ if he possessed at death a general power of appointment with respect to the annuity rights. See Murphy, supra note 27, at 3-25; Waldo, Life Insurance and Anmities under the 1954 Revemue Code, $1955 \mathrm{U}$. ILL. L. Forum 380, 395-96. Similarly life insurance proceeds which are not includible in the gross estate under $\S 2042$ may be includible under some other estate tax provision. Proposed U.S. Treas. Reg. \$ 20.2042-1 (a) (2), 21 FEd. REg. 7885 (1956) ; see INT. Rev. Code of 1954, $\S \S 2035-38,2041 ; 2$ Beveridge $\S 11.01$; Lowndes \& KraMiar 288-89. However, $\$ 2033$ is not applicable to such proceeds. See Singer v. Shaughnessy, 198 F.2d 178 (2d Cir. 1952) ; Proutt's Estate v. Commissioner, 125 F.2d 591 (6th Cir. 1942). Contra, LOWNDES \& KRAMER 46-47.

60. Int. Rev. Code of 1954, § 2033. See Estate of Arthur W. Davis, 11 CCH Tax Ct. Mem. 814 (1952) ; Estate of Leonard B. McKitterick, 42 B.T.A. 130 (1940); Lowndes \& KraMer 50 (collecting cases).

Int. Rev. Code of 1954, § 2041. See Lowndes \& Kranrer 269-70; Bilder, Death Benefits Paid Under an Express Contract, 34 TAxes 529, 531 (1956) ; Murphy, supra note 27, at 24. For examples of death benefits falling within $\S 2041$, see Estate of Eugene F. Saxton, 12 T.C. 569,574 (1949) (dictum) ; G.C.M. 27242, 1952-1 Cum. Bull. 160.

61. Section 2033 provides that "the gross estate shall include the value of all property. ..." Section 2041 states "to the extent of any property. . .." In interpreting the word "property" in these and other estate tax provisions, the courts have resorted to distinctions between "property" and "mere expectancies." See cases cited note 64 infra.

62. See Molter v. United States, 146 F. Supp. 497 (E.D.N.Y. 1956); Dimock v. Corwin, 19 F. Supp. 56 (E.D.N.Y. 1937), aff'd on other grounds, 99 F.2d 799 (2d Cir. 1938), aff'd, 306 U.S. 363 (1939) ; Estate of Albert L. Salt, 17 T.C. 92 (1951); Estate of Emil A. Stake, 11 T.C. 817 (1948).

63. Use of these conditions is discussed at note 26 supra.

64. The principal case is Dimock v. Corwin, 19 F. Supp. 56 (E.D.N.Y. 1937), aff'd ou other grounds, 99 F.2d 799 (2d Cir. 1938), aff'd, 306 U.S. 363 (1939). The contract there involved provided that the benefits granted under the plan were voluntary and specifically reserved to the employer the right to withdraw or modify them at any time. The court held that decedent during life had only the means to enable his beneficiary to receive a grant from the employer; decedent himself possessed a mere expectancy and not a property right. Id. at 58, 59. See also Molter v. United States, 146 F. Supp. 497 (E.D.N.Y. 1956) (terminable right an expectancy, not property); Estate of William S. Miller, 14 T.C. 657 (1950) (same); G.C.M. 17817, 1937-1 Cum. Bull. 281. Contra, G.C.M. 27242, 1952-1 Cum. Bull. 160.

The "expectancy theory" has been expanded to cover a variety of contingencies. The 
practices and therefore amounts to a virtual certainty, this argument has prevailed. ${ }^{65}$

Death benefits are taxable under still other provisions which impose liability upon certain inter vivos property transfers: sections 2035, 2036, 2037 and 2038.66 However, for these sections to operate, not only must there be property which can be transferred, and an actual transfer, but the decedent must have been the transferor as well. ${ }^{67}$ Obviously, opportunities for manipulation are plentiful. For example, under existing law, identification of the transferor turns upon the origin of the plan. If in salary negotiations the employee bargains for death benefits, courts correctly consider him the transferor, reasoning that his performance of services actually effects the transfer of property from employer to beneficiaries. ${ }^{68}$ But when the employer unilaterally establishes death benefits

reasoning in each case is essentially that the employee's right to benefits is subject to a condition and does not vest until fulfillment of the condition or death. The following are illustrative contingencies held to make the right to death benefits an expectancy: (1) the employee must reach a certain age or continue in employment for a specified number of years, Hanner v. Glenn, 111 F. Supp. 52 (W.D. Ky. 1953) ; Estate of William S. Miller, supra; Estate of M. Hadden Howell, 15 T.C. 224 (1950); Estate of Emil A. Stake, 11 T.C. 817 (1948); (2) the employee must not be employed by a competitor, convicted of a felony, adjudged bankrupt or have a judgment for payment of money against him, Estate of William S. Miller, supra; (3) the beneficiary must survive the decedent in order to be entitled to payment, Dimock v. Corwin, supra; see Estate of Albert L. Salt, 17 T.C. 92 (1951).

65. See Estate of Albert L. Salt, supra note 64. Regular death benefits had been paid, as authorized by the plan, to every eligible beneficiary during its entire fifteen year existence. Since payments were "discretionary," however, the court held decedent's interest a "mere expectancy." Id. at 97, 100.

66. INT. Rev. CODE of 1954, §§ 2035-38 (respectively, transfers in contemplation of death, transfers with a retained life estate, transfers by decedent taking effect at death and revocable transfers).

Designation of a beneficiary is a "transfer" within these sections. See, e.g., Adeline S. Davis, 27 T.C. 378 (1956); Estate of William J. O'Shea, 47 B.T.A. 646 (1942); Estate of Stuart Wilson, 42 B.T.A. 1196 (1940) ; Kernochan v. United States, 89 Ct. Cl. 507, 29 F. Supp. 860 (1939), cert. denied, 309 U.S. 675 (1940). Reserved powers to amend or revoke the designation once made are illustrative controls likely to incur taxation of the entire proceeds. See, e.g., InT. Rev. Cone of 1954, § 2038; see also Adeline S. Davis, supra; Proposed U.S. Treas. Reg. § 20.2042-1(c) (4), 21 FED. REg. 7885-\$6 (1956); 2 BenERIDGe § 11.10; Lowndes \& Kramer 48, 288.

67. The cases under these sections also encounter the "property-expectancy" problem. See Hanner v. Glenn, 111 F. Supp. 52 (W.D. Ky. 1953) ; Estate of M. Hadden Howell, 15 T.C. 224 (1950) ; Estate of William S. Miller, 14 T.C. 657 (1950); see also note 64 supra. Under the 1939 Code, the forerunners of $\$ \S 2035-38$ applied to "property transfers." See Int. Rev. Code of 1939, \& 811(c), (d), as amended, 67 Stat. 623 (1953). The 1954 provisions are substantially identical. Consequently earlier decisions failing to find a taxable transfer by the decedent may be currently applicable. See, e.g., Commissioner v. Twogood's Estate, 194 F.2d 627 (2d Cir. 1952) ; Estate of William S. Miller, stpra. See, generally, 2 BeVERIDGe $\$ \S 12.07-08$; Lowndes \& Kramer 154-59; Murphy, supra note 27, at 25-28.

68. See Estate of Paul G. Leoni, 7 CCH Tax Ct. Mem. 759 (1948); see also Estate of William L. Nevin, 11 T.C. 59 (1948). 
and initially, though tentatively, designates beneficiaries for his employees, the designation is not regarded as a transfer by the employee, despite the tenuousness of the distinction. ${ }^{69}$ Because of such formalistic distinctions, employees who receive death benefits subject to neither sections 2039 nor 2042 may avoid estate taxation altogether, ${ }^{70}$ even when they remained factually in control over the proceeds at death. ${ }^{71}$

\section{Evaluation of the Labels}

Estate taxation of most employee death benefits under the 1954 Code is only as workable as the line between sections 2039 and 2042 is clear. Section 2039 expressly contains an outer boundary ; it does not apply unless a decedent employee was entitled to receive some form of inter vivos payment in addition to death benefits. Given this lifetime feature, however, the two sections overlap. For the same plan may confer both "insurance" and "annuity" benefits at different times within a single employee's life span. ${ }^{72}$ Accordingly, a precise distinction between these concepts is essential.

\section{Insurance vs. Annuities-A Functional Approach}

In the leading case of Helvering $v$. Le Gierse, the Supreme Court recognized the earmarks of life insurance as "risk-shifting and risk-distributing." "T3 The insured shifts the risk of financial loss from premature death to the insurer who spreads the loss among all policy holders. ${ }^{74}$ The cost of standard life in-

69. Eugene F. Saxton, 12 T.C. 569, 572, 575 (1949). But see Lowndes \& KRAMER 156.

70. Although these distinctions were made prior to the 1954 Code and therefore need not be currently applicable, many commentators believe they will be carried over. See, e.g., Garner, Income and Estate Taxation of Ammities, N.Y.U. 13TH INST. on FED. TAX. 265, 285-88 (1955); Pyle, Income, Estate and Gift Taxation of Life, Accident and Sickness Insurance and Anmuities Under the 1954 Code, 1956 Tur. TAX INST. 467, 658-59. But see note 128 infra.

71. Since the employer is compensating his employee by means of death benefits, a community of interest for purposes of naming beneficiaries may be inferred.

72. A plan combining insurance protection with annuity features will be taxed as either an annuity or insurance according to the nature of the benefit at death. See note 101 infra. But classification as "insurance" has been inconsistent, depending on the nature of the obligation and obligor. See notes $48-49$ supra. The inconsistency has resulted in confused and divergent estate tax consequences due to the interplay of the following factors: (1) the exclusion of "insurance" from the operation of $\$ 2039$, see notes 14,22 supra; (2) $\$ 2039$ (c)'s exclusion of payments under qualified plans from imposition of the estate tax, see note 11 supra; (3) the apparent limitation of $\$ 2039$ (c) to non-insurance benefits, see note 14 supra; (4) the different tests for taxation provided in $\$ 2039$ and $\$ 2042$. Consequently consistent administration of the tax structure depends on a clear and predictable distinction.

73. 312 U.S. 531,539 (1941).

74. See 312 U.S. at 531.

The text discussion of insurance principles is simplified for exposition and confined to those aspects especially relevant in estate taxation of employee death benefits. On shifting risk to the insurer, see Ackeraran, Insurance 3 (3d ed. 1948) (hereinafter cited as Ackeraran); Allen, General Princtples of Insurance 3-4 (1937) (hereinafter cited 
surance is geared to the insured's life expectancy. ${ }^{75}$ Upon his death prematurely, the face amount of the policy is paid to beneficiaries even though the premiums received by the insurer fall short of the amount it calculated the insured would pay had he lived to the anticipated date. ${ }^{76}$ This difference is loss assumed by other policy holders. Conversely, the insured while alive must incur some of the loss occasioned by the premature deaths of others; his contributions include an amount designed by the insurer to defray mortality costs. ${ }^{77}$ The remainder, less service charges, is "reserved" toward the face amount due at maturity. ${ }^{78}$ In rare instances, an insured who is particularly long lived will contribute enough to meet both the face amount and requisite mortality costs. ${ }^{70}$ At this point, the face amount and what is called "terminal reserve" are equal. Terminal reserve is a mathematically computed variable which on the com-

as Allen) ; Mehr \& Osler 22-23; Riegel \& Loman, Insurance Princtples and PracTrCes 27 (1929) (hereinafter cited as RIEGEL \& LoMraN). For distribution of risk to other policy holders, see Allen 5; Mehr \& Osler 25-30; Riegel \& Loman 27. For discussions of actuarial tables, nature of risks and computation of insurance premiums, see ALLEN 5 , 12-13, 51-55, 107-11; Le VitA, AN ARIThMmetic of Life INsuRANCE 6-21, 94-102 (1936) (hereinafter cited as LE VITA) ; MeHR \& Osler 24, 441-523; Menge \& Glover, AN INtroduction to the Mathematics of Life Insurance 1-19, 48-71, 153-75 (1935) (hereinafter cited as MENGe \& Glover) ; RIEgel \& LoMraN 30-32, 114-32.

75. Other important factors bearing on the premium amount are insurer expenses and interest rates. The expected interest return reduces the cost to the insured. See AlLEN 54-55, 60-63; RIEGEI \& LoMin 119-34.

76. Under an "ordinary" life policy-where the insured pays periodic level premiumsthe insurer loses premiums upon the insured's premature death because the latter is obligated to pay throughout his life. See AcKerman 27-28; Allen 35; RIEgel \& LOMAN 95, 96 (graph), 97. Whether or not an insured would in fact continue to pay after reaching his actuarially predicted life expectancy depends upon such factors as use of insurer dividends to reduce premium payments or acceptance of "paid-up" value as insurance. See Ackerman 33-38; Mehr \& Osler 55-56.

A somewhat different analysis is applicable when single premium or limited payment life insurance plans are used instead of the level premium policy. Obviously, the insured's obligation to pay premiums does not then extend throughout his life or even his life expectancy. See Ackerman 28; Riegel \& Loman 97-98. Still, under a limited payment life policy, if the insured dies prematurely and before all his premiums have been paid, the insurer loses. And if death occurs after final payment, or after payment of a single lumpsum premium but before the actuarially predicted date, the insurer loses the interest which the payments would have earned. The expected interest return is taken into account in computing the cost of the policy to the insured; cost is reduced by this expected revenue. See AlIEN 54-58.

77. See, e.g., Ackerman 70; Rieget. \& Loman 138.

78. See ibid.; note 80 infra. A policy matures when "the face value is paid either by reason of death or by reason of the survival of the insured to the end of a given period." MEHR \& OsLer 56. For discussion of "maturity" in connection with endowment contracts see notes $86-88$ infra.

79. At this point, the insured is actuarially dead. For discussion of contracts other than "ordinary life," see note 76 supra.

An individual is considered "dead" at age ninety-six, since actuarial tables extend only to age ninety-five. See AlLEN 52, 53 ; RIEGEL \& LOAAN 139, 141. And the insurer should then become liable for the face amount of the policy. 
pany's books reflects at any given moment the total amount of premiums received plus interest accumulations at the assumed rate less the total cost of risk distribution. ${ }^{80}$ The terminal reserve figure thus represents that portion of premium payments theoretically set aside which, with accrued interest, will be applied to the insurer's obligation at maturity of the policy. ${ }^{81}$ This concept can be crucial in estate taxation of death benefits. For when terminal reserve equals face amount, no further element of risk shifting or distributing exists under the policy. Thereafter, the proceeds are merely the return of savings and not insurance. ${ }^{82}$

A survivorship annuity, on the other hand, is not insurance precisely because

80. Since insurers must be prepared to meet future demands, monetary "reserves" are essential. Insurance laws generally require reserves to be accumulated on each policy at the end of each year. See AlLEN 66; RIEgel \& LoMran 144-45. This "accumulation," derived from premium payments, is that part of premiums not used to defray mortality costs and other expenses. See AckeRMian 70. In reality, the total amount of premiums plus compounded interest is calculated to satisfy all losses and expenses to be charged against a policy. The net single premium plan clearly illustrates this principle and level premiums are its mathematical equivalent. See AlLEN 58-60, 68, 69. Thus, the part of premiums paid not necessary to satisfy death claims (mortality costs) will equal, with accrued interest, the face amount of the policy at actuarial death. See note 79 sippra; see also Allen 69; Rieger \& Loman 137-39, 140 (table). For clarification, it should be recognized that terminal reserve less the charge for cashing in a policy equals cash surrender value. $I d$. at 137 .

The amount of terminal reserve at any particular time necessarily varies with a number of factors: (1) type of policy; (2) mode of premium payments; (3) age of the insured when the policy is issued; (4) length of coverage; (5) mortality tabulations; (6) interest rate utilized. ACKERMAN 71; Allen 66-67; RIEGel \& LoMan 137-44. For example, the reserve at the end of the first year will be greater on a single premium policy than on the level premium variety, and its size increases proportionately with that of the assumed rate of interest. Moreover, it is evident that reserves are impossible on certain types of premiums such as natural premiums, $i d$. at $120-22$, which are geared to yearly mortality costs and are virtually exhausted at the conclusion of a particular year. See AlLEN 66-67; RIEGEL \& LOMAN 138.

81. Since terminal reserve can be calculated at any time, its most usual definition is in terms of particular policy years. Thus, it has been defined as "that sum which with additions from all future premium receipts, plus interest payments, will pay all future maturities under the policy." Crobaugh, Handbook of Insurance 1278 (1931). However, characterization of terminal reserve as a "fund" on "each particular policy," while endorsed by many authorities, has been criticized. Compare AcKerman 71, ALLEN 66 with RIEGEL \& LoMan 556. The latter authors prefer to regard it as a "liability," not a fund, representing the "total amount" needed by the insurer to satisfy future claims without reference to each particular policy. But the "fund-particular policy" view seems preferable, since the various methods of computing terminal reserve in a given policy year are directed towards ascertaining a fund existing on each policy. See Allen 67-70; Le VITA 34-60; MeHr \& Osler 558-62; Menge \& Glover 72-140. And this view accords with the Commissioner of Internal Revenue's use of the term. See note 101 infra.

82. The regulations adopt this analysis for distinguishing between the "insurance" and "annuity" portions of a retirement death benefit plan. Proposed U.S. Treas. Reg. $§ 20.20$ 39-1(d), 21 FED. REg. 7877-78 (1956). See note 101 infra. But if the plan is not purchased from an insurance company, this approach may not be followed. See note 114 infra. 
it does not shift the investor's risk of premature death to others. ${ }^{83}$ Rather, the typical survivorship annuity is designed to return premiums paid plus interest to the primary annuitant and his designated survivor over the duration of their life expectancies. ${ }^{84}$ If both die prematurely, the amount received under this contract, unlike life insurance, will necessarily be less than the amount contributed. And the unreturned portion is retained by the insurance company for allocation among other annuitants who outlive their life expectancies. ${ }^{85}$

For estate tax purposes, the distinction between insurance and annuity is most crucial when a death benefit plan combines features of both. One such plan is the life insurance endowment contract: it shifts from insurance to savings after the expiration of a stipulated period of time. If the insured dies within this period, his beneficiaries receive the full proceeds of the policy. If he survives, the face amount becomes payable to himself, either in a lump sum or in installments for life with remainder to designated beneficiaries. ${ }^{80}$ The endowment contract is priced so that by the end of the designated period, premiums received will equal the face amount plus mortality costs occasioned by the premature deaths of similar policy holders within the same period. ${ }^{87}$ More

83. Survivorship annuities may be regarded as one of several "investment" contracts sold by insurance companies. Cf. ALLEN 47-48; MeHR \& OsLER 69, 78. The endowment contract is another. Ackerman 21; Crobaugh, HandBook of Insurance 478-80 (1931). But labeling these contracts "investment" is misleading, since life insurance may also be purchased for "investment" purposes. Furthermore, the terminal reserve value of a life insurance contract has been called its "investment" portion. RIEGEL \& LoMaN 94-100 (tables).

A more graphic distinction is in terms of the nature of the risk shifted, for both life insurance and survivorship annuities will involve "risk shifting." The annuity, however, rewards long lived beneficiaries, in contrast with life insurance which benefits only those who die prematurely. See note 85 infra. For estate tax purposes, a generic labul describing "non-insurance" benefits is less important than an ability to determine functionally when they occur. Yet the difficulties of generically distinguishing "annuities" and "insurance" casts fundamental doubt on the estate tax scheme which in $\$ \$ 2039$ and 2042 imposes differing tax principles for each label. See notes 126, 136 infra and accompanying text.

84. See Ackerman 56; Allen 47; Mehr \& Osler 69-70, 78.

85. Thus, although life insurance and survivorship annuities both involve "risk shifting," they are functionally exact opposites. When annuitants die prematurely, the other policy holders are benefited for the cost to them is reduced. Short-lived individuals covered by life insurance increase the costs to similar policy holders by their premature deaths. See AlLEN 41-47; MeHr \& OsLer 69-70; see also notes 74-78 supra and accompanying text.

86. Pure endowment contracts are payable only if the insured lives until the policy matures. ALLEN 43. However, as commonly used, the term encompasses payments to a designated beneficiary in the event of the insured's premature death as well as the obligation at maturity. A more accurate designation of the combined plan is "life insurance endowment contract," since it combines elements of "pure endowment" and "term insurance." "The Endowment policy might be said to be a savings fund protected by Term insurance..." Menr \& Oster 45. See Ackerman 28-29; Alien 43; Riggel \& Loman 98-103.

87. Expiration of the period marks the policy's maturity and is thus the event which obligates the company to commence payment. The terminal reserve will therefore reach 
concisely, the policy's terminal reserve is designed to equal its face amount upon expiration of the period. Accordingly, when the insured dies prematurely and the face amount is paid to beneficiaries, the company necessarily has received less than the amount it calculated the insured would pay had he lived to the end of the period.88 To this extent, the plan is insurance, since loss from the insured's premature death is shifted to the insurer and thereby distributed. ${ }^{89}$ However, once the insured lives beyond the specified date when terminal reserve equals face amount, the policy no longer contains any element of insurance. Instead, all returns by the insurance company then constitute accumulated savings plus interest whether payable to the insured in a lump sum or as a survivorship annuity. ${ }^{90}$ Thus, in a combination life insurance and annuity plan, the pivotal point for differentiating between the two is the date at which terminal reserve equals the face amount of the policy. ${ }^{91}$

\section{Employee death benefits analyzed}

A functional approach should govern estate taxation of employee death benefits under sections 2039 and $2042 .{ }^{.2}$ For the context of an employment relationship does not alter the basic "insurance-savings" characteristics of death benefits. This is most apparent when death benefit plans are obtained by the employer from an insurance company. To the extent the plans so provided are purchased with contributions of the employer, they are, as between employer and employee, simply compensation for the latter's services. ${ }^{93}$ But once respec-

the amount of liability at this point. See Acrerman 71 (table); Menge \& Glover 136 (mathematical details); RIEGEL \& LOMAN 141.

S8. The amount of premiums is computed to satisfy all obligations connected with the policy including insured's share of group death claims, insurer expenses and the terminal reserve figure or insurer liability at the policy's maturity. See RIEGEL \& LOMAN 138; note So supra.

S9. See note 74 supra and accompanying text; note 85 supra.

90. The obligations under the policy have been covered. The terminal reserve figure equals the benefit which the insured will receive, and the insurer is no longer subject to risk. Technically, "term insurance protection" has given way to a return of savings. See MeAr \& OsLer 45. See notes 74, 80, 82, 86-87 supra.

91. This method of distinction is crucial for estate taxation of employee death benefits. See text at note 101 infra. But see text at notes 118-24 infra.

92. Although ambiguous, the estate tax regulations seem to adopt this method for distinguishing insurance from annuities, at least when death benefits are funded through a standard insurance company. See Proposed U.S. Treas. Reg. § 20.2039-1(d), (example), 21 FED. REG. 7877-78 (1956); note 101. infra and accompanying text.

93. The employer agrees to contribute toward retirement and death benefit plans in lieu of higher wages. For the compensatory character of employer contributions to such plans, see O'Nerll 1-12; Bittker, Estate and Gift Taxation Under the 1954 Code: The Principal Changes, 29 TuL. L. Rev. 453, 470 (1955). The compensatory nature of employer contributions is axiomatic in the case of deferred compensation contracts, which may take the form of retirement death benefit plans. The main purpose of these plans is to avoid progressive income tax rates applicable during productive years. Childs, Deferred Compensation Plans for Executives, 31 TAXEs 1007-08 (1953); Lefevre, Deferred Compensation Plans, N.Y.U. 15TH INST. on FEd. TAx. 1081, 1082-83 (1957); Rice, Incentives for Executives of Small Corporations, 32 TAxEs 222, 225-26 (1.954). 
tive shares of the plan's cost are agreed upon, the employer, in so far as the employee's contributions are concerned, is merely a conduit between the employee and the insurance company. ${ }^{94}$ Thus, if the employer procures protection only against loss of earnings through premature death, each policy is in all respects life insurance. ${ }^{95}$ The employer's bargaining position as multiple purchaser from the insurance company merely lessens the cost per policy without affecting the functional character of the individual coverage. ${ }^{06}$

More typically, employer and insurance company arrange combination retirement and death benefit plans. ${ }^{97}$ Often, such plans will shift from insurance to savings within an employee's own lifetime, like the standard life insurance endowment contract, raising similar problems of classification. In an employment context, the pivotal point is ordinarily the date at which the employee expects to retire. ${ }^{98}$ If he dies prior to this date, named beneficiaries immediately receive death benefits. Should retirement age be reached, the employee may elect to

94. If instead the employee received higher wages and purchased identical benefits himself, estate taxation would apparently depend upon a functional analysis. See Proposed U.S. Treas. Reg. \$ 20.2039-1(d), 21 FED. Reg. $7877-78$ (1956). See also note 101 infra. Taxation is similarly determined when the employer, either alone or in conjunction with his employees, purchases a retirement death benefit contract from a standard insurer. See Proposed U.S. Treas. Reg. § 20.2039-1(d) (example), 21 FED. REG. 7878 (1956). But when the employer pays death benefits directly, the functional analysis may not be used. See notes $48-49$ supra and accompanying text.

95. The issue is not disputed. If only insurance benefits are provided and the contract is purchased from an insurance company, the proceeds will be taxed under $\$ 2042$ whether purchased by employees in an individual capacity or by the employer. See note 101 infra. Serious estate tax problems arise only when the plan combines both insurance and annuity features: i.e., when it resembles a standard life insurance endowment contract.

96. The cost of group life insurance per employee is significantly lower than the cost of an individual policy. For this reason, group plans are an increasingly popular form of insurance protection. See ALLEN 112-15; MEHR \& OsLer 273-74; RIEGEL \& LOMAN 223-28.

97. Dearing 1-3; Sibson 9-14; CCH, Pension and Profit Sharing Plans and Clauses 3 (1957). Many plans will also provide insurance protection for the employee during the period of employment. Cardon, Taxation of Compensation, $6 \mathrm{~J}$. TAxation 100, 102 (1957). Combination insurance-annuity benefits are less common under qualified plans, because qualified insurance is disfavored for income tax purposes, see note 17 supra, and because the cost of insurance protection for a substantial percentage of employees may be excessive, Sibson 110. However, group term insurance may be carried in addition to qualified benefits when desired. O'NEILL 320-22. Since non-qualified plans are frequently designed to compensate key personnel, the additional cost is not a deterrent and combination insurance-annuity contracts are commonly used. See Lefevre, supra note 93, at 109596; Cardon, supra at 102.

98. The regulations recognize the importance of the retirement date. See Proposed U.S. Treas. Reg. $\$ 20.2039-1$ (d) (example), 21 FED. REg. 7878 (1956). To illustrate, a typical plan combining insurance protection purchased by the employer from an insurance carrier is the group permanent life insurance contract. This arrangement provides insurance protection prior to retirement. At retirement the insurance feature gives way to a simple or survivorship annuity. MEHR \& OsLER 306-09; WYAtT 73-78; St. John, supra note 47 , at $116-23$. If the number of employees within the plan is not of sufficient size to obtain group coverage, similar provisions are commonly found in individual policies. Couper \& VAughan 47-48; St. John, sipra note 47, at 128-31. 
receive any one of several kinds of annuity payments. ${ }^{99}$ The insurance company under this type of arrangement will calculate premiums to yield an amount at retirement sufficient to meet both the annuity then taking effect and loss from unpaid premiums of similar policy holders expected to die prematurely within the same period. In other words, terminal reserve will equal face amount at or near the specified retirement date. ${ }^{100}$ Contributions on behalf of the insured thus defray the insurer's mortality costs as well as his future obligations on the given policy. When at retirement both these costs are met, the plan becomes an annuity. And the Commissioner has adopted this analysis-based on the terminal reserve figure-for distinguishing insurance from savings, at least when employee death benefits are, as here, purchased from a standard insurance company. ${ }^{101}$

99. See id. at 119,122 . Such a plan is exactly analogous to a life insurance cndowment contract. See notes 86-91 supra and accompanying text.

100. Terminal reserve will equal the face amount at retirement date if, as is frequently: the case, the present value of the annuity then taking effect is equal to the total amount ipayable as insurance prior to retirement. See MEEHR \& OsLER 306-07. Often, howeter, the plan will provide an annuity after retirement which will exceed the face amount payable as insurance prior to retirement. This practice may reflect an employer's intention not to compensate an employee fully unless all his services are in fact performed. In this cvent, the terminal reserve value will exceed the face value of the insurance in the years immediately preceeding retirement, since the insurer must collect the additional funds necessary to meet the annuity coming due at retirement. But the date at which terminal reserve equals face amount will nevertheless mark the expiration of the insurance feature for estate tax purposes. See Proposed U.S. Treas. Reg. $\$$ 20.2039-1(d), (cxaniple), 21 Fev. REG. 7877-78 (1956); notes 79-81 supra and accompanying text. If the employee dies after the date at which terminal reserve equals face amount but before retirement, his beneficiaries will receive the full value of the reserve, including its excess over face amount; but this amount is functionally not insurance. See, generally, AIEur \& OsLER 306-08; Wyatr 74; St. John, supra note 47, at 119. And the terminal reserve will equal face value only shortly before retirement, for the employee will want insurance protection during the time he is most likely to die. See ibid.

101. "If an annuity or other payment receivable by a beneficiary under a contract or an agreement is in substance the proceeds of insurance under a policy on the life of the decedent, section 2039(a) and (b) does not apply ... [ [S]ce section 2042 and $\$ 20.2042-1$. A combination annuity contract and life insurance policy on the decedent's life (eg., a 'retirement income' policy with death benefits) which matured during the decedent's life so that there was no longer an insurance element under the contract at the time of the decedent's death is subject to the provision of section 2039 (a) and (b). On the other hand, the treatment of a combination annuity contract and life insurance policy on the decedent's life which did not mature during the decedent's life depends upon the nature of the contract at the time of the decedent's death. The nature of the contract is generally determined by the relation of the terminal reserve value of the policy to the value of the death benefit at the time of the decedent's death. If the decedent dies before the terminal reserve value equals the death benefit, there is still an insurance element under the contract. The contract is therefore considered, for estate tax purposes, to be an insurance policy subje'ct to the provisions of section 2042. However, if the decedent dies after the terminal reserve value equals the death benefit, there is no longer an insurance element under the contract. The contract is therefore considered to be a contract 
But the functional analysis also seems appropriate when death benefits are paid directly by the employer and not by a commercial insurance company. ${ }^{102}$ The employer may himself finance any type of death benefit sold by an insurance company, whether or not he utilizes the bookkeeping techniques of his

for an annuity or other payment subject to the provisions of section 2039 (a) and

(b) or some other provision of sections 2033 through 2041 . . ."

Proposed U.S. Treas. Reg. $\$ 20.2039-1$ (d), 21 FED. RbG. $7877-78$ (1956). The example is given of a combination retirement-death benefit plan which shifts from insurance to :111 annuity at the retirement date, the terminal reserve then equalling face value by hypothe'sis. Id. example 1.

However, a different analysis is applied for the income taxation of insurance benefits under qualified plans. For purposes of $\S 101$ (a) (1), the terminal reserve value of a policy is denied recognition as "insurance." Instead, only the amount at risk when the insured dies is treated as insurance: i.e., the difference between the total amount collected from the insurer less the value of the terminal reserve. The terminal reserve yalue is taxed as the refund portion of an annuity under $\S 402(\mathrm{a})$. The "insurance" portion-amount at risk-is tax exempt under $\S 101$ (a) (1). As the reserve builds up over the period of employment, the amount at risk necessarily decreases. The "insurance" portion thus varies inversely with the length of service for this limited purpose. See U.S. Treas. Reg. $\$ \$ 1.402$ (a) -1(a) (3), (4) (1956).

This approach has never been employed or argued for estate tax purposes. But cf. Kernochan v. United States, 89 Ct. Cl. 507, 29 F. Supp. 860 (1939), cert. detticd, 309 U.S. 675 (1940); Estate of Benton L. Snyder, 4 CCH Tax Ct. Mem. 957 (1945), discussed at note 114 infra; Estate of Stuart Wilson, 42 B.T.A. 1196 (1940). Ordinarily, if any amount is at risk, the entire proceeds of a standard insurance policy are subject to estate taxation as "insurance" under $\S 2042$, including the full value of the terminal reserve. Only when the terminal reserve equals the face amount and there is no further risk will the procedds not be taxed as insurance. Proposed U.S. Treas. Reg. $\$ 20.2039-1$ (d), 21 FED. REC. 787778 (1956). See, generally, Lawthers, The Individual Life Insurance Policy Issued in Conrection with a Qualified Employee Trust, 35 TAxes 173 (1957). The estate tax analysis which considers terminal reserve value as a part of the insurance proceeds is consonant with customary insurer practices and the traditional definition of insurance established in Helvering v. Le Gierse. See text at notes $73-82$ supra. This is particularly true since, as a practical matter, the "terminal reserve value" is insurance from the insured's point of view, for he can obtain this sum on surrendering the policy only by forfeiting protection against premature death. See note 80 sutpra. The income tax approach is deviational, made necessary by the Code's peculiar, over-all tax scheme for qualified plans, and in that context, may prevent tax avoidance. See U.S. Treas. Reg. § 1.402 (a) -1 (a) (1956), interpreting INT. REv. CODE of 1954, § 402(a) (taxability of beneficiary of a qualified trust).

A distinction between the amount at risk and the terminal reserve value should not bo allowed under the estate tax even if argued. Besides distorting the realities of insurer practices, such an approach would create confusion and thwart congressional intent. For the terminal reserve value would not be taxable as insurance under $\S 2042$, but only under other provisions. And when a combination life insurance-annuity contract is involved, both $\$ 2039$ and 2042 would be concurrently applicable to the respective portions of "risk" and "savings" in the proceeds, if terminal reserve did not equal face amount when the insured died. Such difficulties would be compounded if an employer paid the benefits directly without the aid of an insurance company, since the vital actuarial computations might be lacking. Manifestly, this is not the approach Congress envisioned in passing $\S 2042$ which reaches simply the proceeds of "life insurance."

102. Death benefit plans are either employer self-funded or financed through an insurance company, unless the arrangement is completely informal. See note 47 supra. It is 
professional counterpart. ${ }^{103}$ Since employee death benefits represent compensation in so far as employer contributions are concerned, the employee's services must, to that extent, earn the necessary "premiums" before maturity. The employer's computation of "face amount" is therefore geared to the expected period of service. ${ }^{104}$ Accordingly, an employer providing the typical combination retirement and death benefit plan would, upon an employee's death prior to retirement age, pay a death benefit exceeding the premiums earned through services actually performed. ${ }^{105}$ In this context, the plan resembles insurance.

likely that smaller firms will choose a formal plan with a commercial carrier rather than self-funding, because smaller enterprises risk loss from failure to realize actuarial predictions and from high administrative costs per employee. See Sibson 18; Gordon, Pension and Profit Sharing Plans for Medintm and Small Business, 1955 Tulane Tax INst. 231, 240-41; Loschen, Accounting Aspects of Self Insurance Programs, $99 \mathrm{~J}$. Accountancy Jan. 1955 , p. 50.

An informal, non-funded plan is sometimes no plan at all. The benefits are paid out of general funds, and the employee may have no contractual assurance that he will receive anything. See Couper \& VAughaN 27-29; MeHr \& Osler 294; O'NeIIL 32-37; SibsoN 18-20. But if the primary purpose of the plan is compensation of top executives or other key personnel, an informal, non-funded plan is often used. The employer's obligation is then fairly definite, though the employee's interest is usually forfeitable. See note 26 supra. And under a non-funded plan, the employer is generally entitled to an income tax deduction in the years when compensation is paid, INT. REv. CoDE oF 1954, $\$$ 404(a) (5); U.S. Treas. Reg. $\$ 1.404$ (a)-12 (1957) ; see also Lefevre, sipra note 93, at 1094-98, while contributions to a funded plan favoring key employees may never be deductible. For such contributions are deductible only if the plan qualifies under $\$ 401$. See INT. REv. Code or $1954, \S 404$ (a) (2). And a plan discriminating in favor of key employe'es cannot qualify. Note 12 supra.

103. If the plan is self-funded, the services of an actuary are commonly employed. O'NEILL 174-75; SIBSoN 20-21. It does not necessarily follow that self-funding employers will make conservative estimates based on sound mortality and interest assumptions when computing the cost of their obligations. In fact, there may be a tendency to underestimate costs, since liabilities will be minimal in early years. See MeHR \& OsLER 295. Generally, however, an employer will attempt to approximate the actuarial computations of a standard insurer, in order that his contributions will be just sufficient to cover all future obligations. The more formal, conscientious and well organized the self-funded plan, the more closely the employer's methodology will resemble that of a miniature insurance company.

On the other hand, if the plan is on an informal or pay-as-you-go basis, it is unlikely that the employer will rely on actuarial principles in the manner of a standard insurer. See SIBSON 19; O'NeIL 35-37. These employers are more interested in deferred compensation than the mechanics of risk shifting; any "loss" thus occasioned is merely compensation which the employer expects to pay in any event. Nevertheless, even such informal payments may functionally correspond to the payments of a more formal operation for estate tax purposes. See text at notes 121-24 infra.

104. The employee's services correspond to the payment of premiums. Otherwise the employer may encounter higher costs than the value of the employee's services warrant. In some cases, however, the employee may continue employment in an advisory capacity after "retirement." The value of post-retirement services could be included in computing the costs of insurance protection. But generally retention in such capacity would not affect the employer's calculations, and should not be significant for estate tax purposes. See note 124 infra.

105. An employer would rarely provide pure insurance with no lifetime feature without the aid of an insurance company, cf. Loschen, supra note 102, at 50, and thus will more 
After retirement, on the other hand, the death benefit would probably represent merely a return of the employee's accrued earnings. ${ }^{106}$ Within this framework, the employer's administration of his plan may more or less parallel the operations of a commercial insurer, depending on his objectives. ${ }^{107}$ Actuarial principles may be utilized. ${ }^{108}$ For example, the "face amount" of the death benefit may take into account interest to accrue upon the employee's earnings between his retirement and expected date of death. ${ }^{109}$ Upon premature death, a beneficiary would then receive unearned interest as well as unearned compensation. ${ }^{110}$ Conversely, long-lived employees would defray loss from premature death, since their earnings would contribute unexpected interest to the employer. ${ }^{111}$ Moreover, the employer can even duplicate the insurer's "terminal reserve" operation by deducting actuarially predicted mortality costs from projected earnings. In this manner, risk can be spread among all participating employees, though actuarial calculations are necessarily less certain due to the small sampling of individuals involved. ${ }^{112}$ But such intricate calculations are

probably combine retirement income with death benefits. As compensation, such plans reward the employee after his services have been rendered. Nevertheless, some insurance against premature death prior to retirement is likely to be included, although the benefits payable before that date may be less than the amount due thereafter. This is often the case when commercial insurance contracts are used. See notes 98,100 supra.

106. Retirement in a death benefit-retirement pian is analogous to the maturity date of a life insurance endowment contract. At maturity, all future benefits will have been paid by past premiums and the annuity feature commences. Similarly, by retirement, the employee will have earned all contributions on his behalf through past services, see note 104 supra, and he is then entitled to receive retirement or other benefits. As in the life insurance endowment contract, the insurance risk ceases when the retirement death benefits have been earned in full by past services. At this point, the employee is no longer shifting risk of premature death, for the payments merely represent accumulated, accrued earnings which he has deferred until retirement.

107. See note 103 supra.

108. The employer's calculations may include mortality and interest assumptions, in addition to the value of the employee's services. For other pertinent factors, see O'NerLI $75-89$; note 103 supra.

109. If the employer systematically allocates funds to meet costs over the period of anticipated employment, interest will be earned throughout that period. Conceptually, this is true even if the plan is non-funded, for the employer will be using the funds within the enterprise and thereby earning "interest." See notes 75,76 supra. But if the funds are not segregated, interest assumptions become highly conjectural, since the "interest rate" would vary with the success of the enterprise.

110. The amount of contributions on behalf of an employee, plus interest, should equal the total payable benefits at the expected date of his death. Although all contributions will generally have been made before retirement, if the employee dies prematurely, but after retirement, the benefits payable must include the interest that would have been earned had the employee survived to his life expectancy.

111. If the employee elects a simple or survivorship annuity, the employer retains portions of the principal for a longer period. The amount paid should thus include interest earned while the principal is retained. For an example of typical options available at retirement, see Knight v. Finnegan, 74 F. Supp. 900, 901 \& n.2 (E.D. Mo. 1947).

112. The actuarial sampling is necessarily smaller in the case of a self-insurer. The smaller the sample, the less are the chances of realizing actuarial predictions. Even the 
not essential. For the employer can more easily provide informal insurance protection by merely agreeing to pay a sum upon the employee's untimely death which will exceed to some extent the amount of earnings to be allocated for this purpose over the employment period. True, the employer would have to assume loss occasioned by premature deaths as a cost of the enterprise. And such loss would be distributed among the employer's customers rather than the insured group. While the employer may thus not distribute loss as successfully as an insurance company, he nevertheless protects his employees against loss of earnings through untimely death. ${ }^{113}$ From the latter's viewpoint, therefore, the precise functions of insurance are fulfilled. Consequently, the reluctance of the Commissioner and the courts to classify employer-paid benefits as insurance seems unwarranted. 114

On the other hand, arguments supporting this attitude can be advanced. First, the language of section 2042 itself may exclude contracts not issued by a stand-

most careful calculations may thus not reflect the actual costs of the protection provided. When cost is underestimated, the employer must make up the difference out of general funds. This fact may lead an employer to abandon strict actuarial principles, especially where "loss" is merely deferred compensation he expects to pay. See note 103 supra. Or it may be desirable for the smaller company to adopt a plan issued by a standard insurer. Sibson 18; Gordon, supra note 102, at 241 n.24.

113. Loss from premature death is shifted to the employer's enterprise. The employer distributes this loss among his customers via the price of his products. An insurance company distributes loss among its customers via the price of the policies issued. "Risk shifting" and "risk distributing" are the hallmarks of insurance. See text at note 73 supra.

Nevertheless, the absence of a formal mechanism for risk shifting and risk distributing does not affect the functional character of the benefits paid. If at death the employee receives more than his services have earned, the death benefits are insurance: loss from premature death is shifted to the enterprise and thereby distributed. And such insurance will generally expire at retirement, for benefits paid thereafter will represent accumulated earnings over the period of service.

114. For discussion of the ambiguities in the regulations, see text at notes $48-49$ supra. A major source of confusion is in the congressional reports of the 1954 Code, which seem to perpetuate the distinction between death benefits paid by the employer and those financed through an insurance company. The following example of an employer financed "annuity" taxable under $\$ 2039$ appears in S. REP. No. 1622, 83d Cong., 2d Sess. 472 (1954) and H.R. Rep. No. 1337, 83d Cong., 2d Sess. A315 (1954).

"(4) A contract or agreement entered into by the decedent and his employer under which at decedent's death, prior to retirement or prior to the expiration of a stated period of time, an annuity or other payment was payable to a designated beneficiary if surviving the decedent."

The benefits depicted in the example may functionally confer insurance protection in addition to constituting an annuity. For were the employee to purchase identical benefits from an insurance company, the benefits would be considered term insurance if the insured by dying prior to retirement or prior to a stated period of time could receive more than the premiums paid to the date of death less mortality costs. See text at notes 78-82 supra. Of course, the language employed in the example is ambiguous, and open to different interpretations. For instance, if the plan illustrated merely returns premiums in the event of premature death, as in a refund annuity, the benefits are not functionally insurance. See text at notes 83-85 supra. But many plans do provide insurance protection prior to retirement. See notes 97 supra, 122 infra. To the extent that this fact is recognized and incor- 
ard insurance company, since it purports to reach only insurance proceeds receivable under "policies."115 But this technical construction is not convincing in view of the senseless consequences to both qualified and non-qualified plans it produces. ${ }^{116}$ Instead, the customary interpretation that the word "policy" under section 2042 encompasses any contract or agreement performing the function of insurance seems preferable. 117 A more persuasive argument against treating direct employer payments as insurance can be premised on the fact that only insurance companies usually maintain a working terminal reserve figure for each policy issued. On this view, courts are unable to patrol the line between insurance and savings absent a terminal reserve figure ${ }^{11 s}$-a

porated by the example, it implicitly excludes employer-financed insurance from $\S 2042$ and requires its taxation under $\S 2039$.

The language of the congressional example is so ambiguous, however, that doubt exists as to whether the benefits depicted would in any event be subject to $\$ 2039$ itself. Lacking an explicit lifetime feature, unless the example is interpreted to imply such a provision or is read in conjunction with other examples which do so provide, it may be irreconcilable with the language of $\$ 2039$. See Bittker, Estate and Gift Taxation under the 1954 Code: The Principal Changes, 29 Tul. L. Rev. 453, 469 \& n.58 (1955) ; Note, 6 Stan. L. Rev. 473, 487-89 (1954); 3 RIA, FED. TAX COORDINATOR R-4406. At least one author suggests that the employee's salary fulfills this requirement, and that the example is in this way consistent with the statute. See Pyle, Income, Estate and Gift Taxation of Life, Accident and Sickness Insurance and Annities under the 1954 Code, 1956 Tur. TAX Inst. 467, 654-55. In any event, the example denies "insurance" recognition to benefits functionally insurance so long as it can be assumed that the employee's premature death would result in a payment to his beneficiaries exceeding the value of his contributions. See note 48 supra. The case law may be interpreted to approve classification of employer insurance payments as "insurance." See Commissioner v. Treganowan, 183 F.2d 288 (2d Cir.), ccrt. denied, 340 U.S. 853 (1950). See also Kernochan v. United States, 89 Ct. Cl. 507, 29 F. Supp. 860 (1939), cert. denied, 309 U.S. 675 (1940) ; Estate of Benton I. Snyder, 4 CCH Tax Ct. Mem. 957 (1945) ; Estate of Stuart Wilson, 42 B.T.A. 1196 (1940). The three latter cases involved New York City employee retirement systems which provided an amount approximately equal to one year's salary plus a return of contributions to the beneficiary of an employee dying prior to retirement. Employees living to retirement age received an annuity for life or any of the typical annuity options. The courts correctly held the one year salary amount to be insurance, despite the absence of a commercial contract. But contributions refunded in conjunction with the salary payment were denied classification as insurance. To the extent that both employee contributions and posthumous salary were integral parts of one arrangement, this result seems incorrect. See Helvering v. Le Gierse, 312 U.S. 531 (1941). The total proceeds would appear more properly classifiable as insurance. See note 101 supra.

115. See nate 34 supra.

116. Non-qualified employer-financed insurance would be taxed according to the stricter contribution test of $\S 2039$ rather than the control test of $\S 2042$. See text at notes 22-24 supra. Qualified insurance proceeds would receive immunity not available if paid under a commercial policy. See text at notes 54-55 supra. These consequences are haphazard and without policy justification.

117. Insurance contracts issued by fraternal societies are currently within $\$ 2042$. See Proposed U.S. Treas. Reg. $\$ 20.2042-1$ (a), 21 Fed. REg. 7885 (1956). See also 2 Beveridge \$ 11.02; Lowndes \& Kraner 290-93; 3 RIA, Fed. Tax Coordinator R-4015.

118. The regulations emphasize that annuities and insurance are distinguishable by the relation of the policy's terminal reserve to face amount at death. Proposed U.S. Treas. 
disability which enables employers to confer maximum estate tax advantages by juggling the character of a plan as the need arises. ${ }^{119}$ The possibilities for maneuvering are real, since for purposes of sections 2039 and 2042, the same plan may be insurance or annuity at different times. ${ }^{120}$

Nevertheless, absence of a terminal reserve computation should not of itself preclude classifying death benefits as insurance. In effect, refusing insurance classification would conclusively presume all employer-paid benefits to be merely returned earnings. ${ }^{121}$ Yet, from the employee's perspective, death benefits are often attractive precisely because they assure his beneficiaries of an amount exceeding earnings in the event of premature death. And when the employer's plan is designed to compensate key executives and others for whom the estate tax is relevant, insurance type benefits are especially likely. ${ }^{122}$ These benefits should not receive inconsistent tax treatment merely because sections 2039 and 2042 are less conveniently differentiated absent a formal terminal reserve figure.

Reg. \$ 20.2039-1(d), 21. FED. REg. 7877-78 (1956). When the actuarial data from which "terminal reserve" is calculated are lacking, the Commissioner's basis for distinction is non-existent. Although not expressly stated in case law or regulations, it is likely that the absence of terminal reserve data accounts for the reluctance to categorize benefits as "insurance" when not paid by a standard insurer.

119. For example, the employer might arrange to provide death benefits always in excess of a putative "terminal reserve." If employees divest themselves of control, such benefits would pass free of the estate tax, assuming the "insurance" category of $\S 2042$ were continually applicable. See text at notes $34-38$ supra. This manipulation would also benefit the employer, since the net contributions necessary to provide a tax free benefit would be less than the amount needed to produce the same benefit after taxe's. The regulations anticipate tax avoidance by means of terminal reserve manipulation:

"Notwithstanding the relation of the terminal reserve value of the death benefit, a contract under which the death benefit could never exceed the total premiums paid, plus interest, contains no insurance element."

Proposed U.S. Treas. Reg. $§ 20.2039-1$ (d), 21 FED. REg. 7877-78 (1956). Nevertheless, detecting the strategem from the books of a private company would prove a formidable obstacle.

120. See note 72 supra and accompanying text.

121. The classification is crucial, since if the employee possessed any right to receive payment during his life, the death benefits will generally be taxable under $\$ 2039$ when not taxable under $\$ 2042$. See notes 14, 22-24 supra and accompanying text. There are a few exceptions taxable under neither section. See text at note 57 supra. But, in contrast with $\S 2042$, the liability of $\S 2039$ is not easily avoided. See text at notes $22-24$ supra. And most death benefits-whether employer or commercially operated-will in fact confer upon the employee a right to payment during life. See authorities cited note 97 supra. Accordingly, denial of "insurance" status to employer-paid benefits has serious tax disadvantages for the employee and his beneficiaries. Some employees participating in qualified plans would, however, benefit from this treatment. See text at notes 54-55 supra.

122. See note 20 supra. The families of high income employees stand to lose heavily upon premature death of the wage earner. And the high incidence of early death among corporate executives and others similarly situated is notorious. For these reasons, high income employees particularly welcome protection against premature death. While employers may understandably be unwilling to confer as large a death benefit before retirement as after, see note 100 supra, insurance benefits for executives and others will nevertheless be substantial. 
Instead, sounder approach would counteract the absence of terminal reserve by evaluating direct employer-payment plans in terms of the recurring characteristics of standard plans sold by insurance companies. Thus, when the employer's plan provides no retirement or other life time feature, death benefits should be presumed insurance unless the Commissioner proves otherwise. In rebuttal, the Commissioner might show that the plan returned deferred savings with no element of risk shifting or distributing, or that when benefits were paid, the employee's earnings or contributions on his behalf already covered the costs of risk distribution as well as the face amount. ${ }^{123}$ Similarly, when employeroperated plans embody retirement features, death benefits should be presumed insurance prior to retirement and savings thereafter, again subject to a contrary showing by the employee's estate. ${ }^{124}$ These presumptions would minimize

123. Of course, mortality distribution may not be used when the employer pays benefits directly. And the information necessary to prove that such costs had already been defrayed, or that merely deferred earnings were returned, would be difficult for the Commissioner to obtain. Nevertheless, prior to retirement, direct employer death benefits most likely do return some unearned compensation and are therefore functionally insurance. Correlating their tax treatment with that afforded commercial contracts would accordingly seem proper.

124. When a combination retirement-death benefit plan which includes insurance coverage is purchased from an insurance company, terminal reserve will equal face amount at or near the retirement date. See note 100 supra. This date is similarly emphasized by the regulations. See Proposed U.S. Treas. Reg. \$ 20.2039-1(d) (example), 21 FEd. REg. 787778 (1956). The presumption accords factually with most arrangements. See note 100 supra. Often, however, plans will require the employee to remain with the enterprise in an advisory capacity after retirement as a condition to receiving death benefits. Where the plan is intended to defer income, such a condition is especially desirable for income tax purposes. See Lefevre, supra note 93, at 1086-89; Allison, Deferred Compensation of Execttives, 1954 TUL. TAX INST. 105, 119-21. See also note 26 supra. The existence of such a condition gives rise to the argument that death benefits paid after retirement also include unearned compensation, since the employee's consultation services would presumably be included when computing the cost and amount of death benefits he will receive. This argument, if successful, would result in $\$ 2042$ coverage for benefits paid after retirement. But the contractual obligation to serve as consultant after retirement is a poor guide for distinguishing between insurance and annuities. For the consultation provision is actually a polite form of retirement, and the condition itself is used primarily for its income tax advantages. See note 26 supra. Accordingly, the presence of this condition should be disregarded for estate tax purposes, and the retirement date should constitute the pivotal point for distinguishing between $\S 2039$ and $\S 2042$ when the employer pays benefits directly.

Use of the retirement date as the distinguishing factor may, however, accasion some tax loss for the Commissioner. Frequently, combination insurance-annuity contracts purchased from an insurance company shift from insurance to annuity somewhat earlier than the retirement date. See note 100 supra. Since terminal reserve equals face amount at the date when the shift occurs, the Commissioner can easily detect the expiration of the insurance feature. When, however, a similar plan is financed directly by the employer without use of an insurance company, it would be difficult for the Commissioner to prove that the benefit was "paid up" prior to retirement. Consequently, some employees dying shortly before retirement would, under the suggested presumption, receive $\$ 2042$ treatment even though technically the insurance feature may have expired. Nevertheless, absorbing this 
tax avoidance potential by restricting the opportunities for manipulating death benefit plans after the death of a participating employee, and encourage employers to adopt bookkeeping techniques comparable to the terminal reserve method when aberrational benefits are provided. ${ }^{125}$ In this manner, the characteristics of standard plans sold by insurance companies can be used to avoid arbitrary tax results which follow when direct employer benefits are denied recognition as insurance within section $2042 .{ }^{126}$

\section{The Functional Approach and the Anomalous Category}

Use of a functional analysis would also prevent certain employer-paid benefits from escaping taxation. The area beyond sections 2039 and 2042 may include a limited number of non-qualified, employer-paid insurance benefits which would fall within section 2042 but for the restrictive definition of insurance. ${ }^{127}$ Absent a lifetime feature, these benefits cannot be reached as annuities under section 2039. Unless the Commissioner accepts a functional definition of insurance, they will occupy a third area and may be sheltered from taxation by the semantic technicalities attending application of the terms "property" and "transfer." Moreover, these technicalities have improperly determined estate tax treatment of employee death benefits in that area. ${ }^{128}$ For considering the em-

slight tax loss seems preferable to denying arbitrarily all employer-paid insurance the advantages of $\S 2042$. Mioreover, use of the retirement date presumption is desirable because it provides a workable approach to taxation of employer-paid benefits consistent with the tax treatment of commercial plans and the over-all scheme of $\$ \S 2039$ and 2042.

125. Employers wishing to extend insurance coverage beyond retirement would formalize their computations in order to prove that the benefits were not previously earned or "paid up."

126. Even apart from tax avoidance problems, the suggested presumptions are desirable. The "terminal reserve" concept relied on by the Commissioner for distinguishing between $\S 2039$ and $\S 2042$ is merely a matter of administrative convenience necessitated by the statutory differentiation of "annuities" and "insurance." It is no more or less than a technical bookkeeping device useful in the insurance business for purely professional reasons. Convenience does not necessarily make sound tax policy. The mere absence of terminal reserve from employer-paid benefits should not justify a treatment of these plans inconsistent with others that provide functionally identical benefits. The fault, if any, lies with the statutory distinction which makes the task necessary and not with the taxpayer. In the interest of predictable and consistent tax results, therefore, the presumptions seem preferable to sui generis treatment of employer-paid benefits.

127. See note 48 supra.

128. See text at notes 59-71 supra. The Internal Revenue Service has ruled that the mere possibility of an employer terminating a plan does not indicate the absence of a "property" interest and has recommended that the Dinock v. Corwin line of cases, note 64 supra, no longer be followed. G.C.M. 27242, 1952-1 Cum. Bull. 160. See Lowndes \& Krasrer 51-52, 156; Note, 6 Stan. L. Rev. 473 (1954). But see Molter v. United States, 146 F. Supp. 497 (E.D.N.Y. 1956) ; Nelson, The New S5,000 Death Benefit, 31 TAXES 629, 632 (1953). Moreover, commentators have suggested that decisions which fail to find a "transfer" or a "transferor" are unreal. See LowndEs \& KRAMIER 156-57; Note, 6 Stan. L. Rev. 473, 478 (1954).

Reliance on technical distinctions is particularly harmful in this area, since the employer's payments may escape taxation altogether. The gift tax is inapplicable, since the 
ployee's "expectation" at death less than a property right is unrealistic. ${ }^{120}$ Although an employer may theoretically forfeit death benefits, employee pressures restrict the exercise of such power. ${ }^{130}$ And conditions of forfeiture are often sham, primarily concocted for tax advantages. ${ }^{131}$ More accurately, therefore, the employee's right vests when the plan is established, subject only to divestment before death. ${ }^{132}$ Similarly, the "transferor" requirement is unpersuasive. The employee is no less the economic source of the benefits when the employer names beneficiaries than when the appointment is his own. In both cases the benefits represent compensation to the employee, and the transfer is effectuated by performance of his services. ${ }^{133}$

Because employee death benefits in this area are in principle the same as those taxed by sections 2039 and 2042, precedents enabling them to escape taxation should be overruled. ${ }^{134}$ Since these benefits are clearly without lifetime features, taxation should resemble current treatment of insurance : retention of control over proceeds at death portends tax liability. Employees willing to divest themselves of control more than three years before death would continue to avoid taxation, just as owners of interests in insurance may avoid liability under section $2042 .{ }^{135}$ Overruling precedents entangled in property law refinements would, of course, have the further advantage of eliminating the anomalous juxtaposition of property law with contributions and control as the basis for estate taxation of employee death benefits.

same problems of "property" and "transfer" prevent its imposition. See INT. REv. CoDE of 1954, $\$ \$ 2501,2511$. And the context of an employee-employer relationship makes it doubtful that payments would be "gifts."

129. This is the position taken by the Internal Revenue Service. See authorities cited note 128 supra.

130. "[E] conomic and moral pressures ... as a practical matter preclude the revocation of the plan ...." and unfavorable modifications of the plan by the employer would be “. . . so certain to meet with powerful employee opposition, . . . that employers may find them virtually impossible to carry out." Lowndes \& KRAMER 51-52, 156. See also Note, 6 Stan. L. Rev. 473, 479 (1954).

131. See notes 3,26 supra.

If the possibilities of forfeiture are real, one approach might be to consider the contingencies in the valuation of benefits, rather than holding the interest a "mere expectancy." See Childs, Deferred Compensation Plans for Executives, 31 Taxes 1007, 1020 (1953); Note, 6 Stan. L. REv. 473, 479 (1954). But a recent decision held that the possibilities of forfeiture rendered decedent's right to receive $\$ 6,000$ per year for fifteen years valueless since the benefit had no fair market value. Goodman v. Granger, 56-1 U.S.T.C. If 11595 (W.D. Pa. 1956), rev'd on other grounds, 243 F.2d 264 (3d Cir. 1957).

132. See Estate of Albert B. King, 20 T.C. 930 (1953). Apparently the Tax Court regarded the forfeiture provisions as a condition subsequent. The decedent was held to have a vested property intere'st not made contingent by the mere possibility of divestment. Thus, the entire amount credited to decedent's account was included in his gross estate. It has been suggested that this case may open up a wide vista for the Commissioner to strike down conditions. Childs, supra note 131, at 1019-20.

133. See notes 28,30 supra.

134. See authorities cited notes 28,30 supra.

135. See text at notes 34-38 supra. By making the transfer more than three years prior to death, the employee would escape taxation as a transfer in contemplation of death. INT. REv. CODE OF 1954, § 2035. 


\section{The Broader Perspective: Conststency Needed}

The divergent treatment accorded employee death benefits reflects a basic equivocation in the estate tax. Three different approaches yielding widely dissimilar results are presently utilized. If death benefits are considered insurance within section 2042, the proceeds are includible in the employee's gross estate only if at death he controlled their disposition. If, however, the annuity classification of section 2039 is applicable, the employee's gross estate includes benefits attributable to contributions irrespective of control. Death benefits falling within neither category will at worst be subject to a control test similar to that of section 2042, and if current case law is not overruled, may in some instances be completely immune from estate taxation regardless of control or contributions. Adding to this confusion is the special category of "qualified plans" which specifically exempts some annuities from taxation, but no insurance proceeds.

From a policy perspective little justification for these conflicting principles appears. Although insurance and annuities functionally differ, this distinction bears no discernible relationship to any rationale that might underlie an estate tax. On the contrary, the distinction between annuity and insurance is most often a matter of time and chance. Before the terminal reserve value or some equivalent equals the face amount of a policy, the employee may possess insurance; thereafter, the proceeds constitute an annuity or other form of savings. Yet, this difference is essentially the employee's gamble on his own life; if death is premature, the bet is won, while it is lost if he is long-lived. Certainly, the incidence of estate taxation should not be predicated upon the success of a gamble. And the distinction is entirely without genuine significance when liability for insurance but not "annuities" is avoidable by divestment of control.

An acute need thus exists for correlating various provisions of the Code into a uniform scheme for estate taxation of employee death benefits. Reform should extend to both qualified and non-qualified plans. The advantages of a qualified plan should be made available for insurance proceeds payable under a plan which otherwise meets the requirements of section 401 . To the extent that section 2039 (c) validly exempts qualifying annuities, discrimination against insurance proceeds under similar plans is unwarranted. For non-qualified plans, a single principle of taxation should be chosen. If control is considered the better approach, liability under section 2039 should be placed upon the same footing. If the contribution method is preferred, something like the premiumpaid test must be reintroduced for insurance into section $2042 .{ }^{136}$ In either

136. After long history of vacillation, the premium payment test was abandoned in 1954 because "no other property is subject to estate tax where the decedent initially purchased it and then long before his death gave away all rights to the property." H.R. REP. No. 1337, 83d Cong., 2d Sess. 91 (1954). The repeal, however, met vigorous dissent: "But life insurance is not like other property. It is inherently testamentary in nature . . . We predict that if this provision becomes law, it will virtually do away with estate taxation of life insurance ...." id. B14 (minority report); and a recent bill would reintroduce the premium payment test on a limited scale, see note 34 supra. For an illuminating dis- 
case, the scope of both sections should be expanded to encompass those death benefits now occupying an independent position, closing the loopholes presently available for some plans. Which of these conflicting principles of taxation should ultimately govern is debatable. The need for consistent estate tax treatment of employee death benefits is beyond question.

cussion of the merits of various principles for the taxation of life insurance, see 32 AMERICAN LAw Institute Proceedings 101-20 (1955), reprinted in Warken \& Surrey 513-27.

Although the repeal has been criticized, it has been suggested that if the decedent divested control during life, the premium payment test imposed an inequitable burden since the assignee could at any time surrender the policy. See WARREN \& SurRey 528. Consequently, when the decedent divested control, the premium payment test could equitably be applied only to the difference between the cash surrender value and the face amount payable at death. See ibid.; Lowndes \& KRAMER 281. But the premium payment test may be justified. Inter vivos assignment, even if without the three-year limitation, can be likened to a gift in contemplation of death. See WARREN \& SurRey 529. 